\title{
PHYSIOLOGICAL AND GENETIC PERFORMANCE OF SOME RICE GENOTYPES GROWN IN MEDIUM AND HIGH SALINITY SOILS
}

\author{
B.A. Zayed ${ }^{(1)}$, O. A. M. Ali ${ }^{(2)}$ and S.A. Hammoud ${ }^{(1)}$ \\ (1) Rice research and training center, Field crop research institute, ARC, Egypt. \\ (2) Crop Science Dept., Faculty of Agriculture, Menoufia Univ., Egypt
}

Received: Aug. 14, 2016

Accepted: Aug. 30, 2016

ABSTRACT: Salinity is a common abiotic stress that seriously negatively affects rice production in the world. The investigation was carried out at the Experimental Farm of El-Sirw Agricultural Research Station, Damietta governorate, Egypt to investigate the effect of soil salinity levels (6 and $11 \mathrm{dS} \mathrm{m}^{-1}$ ) on the morphological, leaf chemical constituents and yield traits and phenotypic and genotypic parameters of twelve rice genotypes (Giza 177, Giza 179, Giza 182, Egyptian Jasmine, GZ 10303, GZ 10305, IET 1444, GZ 10286, GZ 9399, GZ 9461 , PLGF101 and Egyptian Hybrid 1) during 2014 and 2015 seasons. The obtained results could be outlined as following:

1- The high level of salinity negatively affected growth parameters (leaf area index, dry matter production and chlorophyll content) and yield related characteristics (heading date, plant height, number of tillers hill ${ }^{1}$, number of panicles hill ${ }^{1}$, panicle length, number of filled grains panicles $^{-1}$, 1000-grain weight, grain yield, biological yield and harvest index) in both seasons. It was detected that increasing salinity sharply decreased rice grain and biological yields with reduction percent amounted to 43.66 and $33.81 \%$ for grain yield and biological yield, respectively. On the other side, increasing salinity significantly increased proline content, $\mathrm{Na}^{+}$ $\%$ and $\mathrm{Na}^{+} / \mathrm{K}^{+}$ratio while decreased $\mathrm{K}^{+} \%$ in rice leaf.

2- The different genotypes were significantly varied among each other in their growth and yield. Egyptian Hybrid 1 surpassed other tested genotypes in growth parameters, number of tillers and panicles hill ${ }^{1}$, panicle length, number of filled grain panicle ${ }^{-1}$ and grain and biological yields $\mathrm{ha}^{-1}$ in both seasons as compared with the other rice genotypes. On the contrary, the rice genotype of Giza 179 had the lowest unfilled grains panicle ${ }^{-1}$. The salt tolerant rice genotypes (Egyptian Hybrid 1, Giza 179, GZ 9399, GZ 9461 and IET 1444) had higher proline content and potassium \% and lower $\mathrm{Na}^{+}$and $\mathrm{Na}^{+} / \mathrm{K}^{+}$ratio, while the sensitive salt rice genotypes showed opposite pattern.

3- The interaction between the tested rice genotypes and salinity levels was significant for studied traits in both seasons. In general, Egyptian Hybrid 1 genotype was superior for the most growth and yield traits when it was grown on medium or high salinity levels followed by GZ 9399 and GZ 9461 genotypes. However, PLGF 101 genotype had the worst performance followed by GZ 10303 and Giza 177 rice genotypes. It could be concluded that Egyptian Hybrid 1 genotype had considerable affinity for withstanding salinity stress to tested levels under the experimental salinity conditions. The maximum reduction for grain yield (65.94 and 66.83\%) was produced by planting Giza 177 and Giza 182 genotypes in the first and second seasons, respectively. However, the lowest reductions (23.59 and 18.85\%) were obtained by growing Egyptian Hybrid 1 and GZ 9399 in the first and second season, respectively.

4- The phenotypic coefficient of variability (PCV) was slightly higher than those of genotypic coefficient of variability (GCV) for all studied traits of the twelve rice genotypes grown under the salinity levels. The value of GCV \% was varied from 21.44 to 41.93 but in PCV\% ranged from 23.68 to 52.99 for grain yield. In most characteristics the increasing salinity level raised the contribution of environmental variability in phenotypic variability. High heritability $\left(H^{2} \%\right)$ estimates in broad sense were detected for most studied traits.

Key words: Salinity, Rice genotypes, Growth, Yield, Genetic parameters. 


\section{INTRODUCTION}

Salinity is a common abiotic stress that seriously negatively affects agricultural production in different regions around the world, particularly in Egypt. Increasing demand for agricultural products have made salinity oriented problems urgent (Hamayun et al., 2010). Generally, salinity problem is everlasting and increasing in Egypt with increasing salt concentration in irrigation water, water shortage, climate changes and low precipitation. Salt stress causes many adverse effects on growth development, physiological process, yield and its quality of crops (Gupta and Huang, 2014), due to a high osmotic potential of soil solution. In the absence of particular-ion effects, crop growth reduction due to salinity is mostly related to the osmotic potential of the rootzone soil solution. Salts stress is affect on different physiological and biochemical traits which forestall or defer germination and consequently lead to abnormal growth and reduction in crop productivity (Mohammadi et al., 2010 and Aref and Rad, 2012).

Increasing salinity can cause soil degradation which is considered as an environmental impairment with severe adverse effects on agricultural productivity, particularly in arid and semiarid regions (Qadir et al., 2006) such as Egypt. Saline soils contain more soluble salts amounts including sodium chloride. Saline soils can be reclaimed by washing with excess of water which can leach and remove the soluble salts out of the root-zone. In addition, such soil can be cultivated with plant species that can manage their growth under salinity stress. In last years, about $6.5 \%$ (831 million ha) of the world's total area (12.78 billion ha) is affected by salt in soils (FAO, 2008), as a result of salts accumulation during long periods of time in soils or groundwater. In Egypt, rice is planting in the northern delta, according to soil survey reports, it had been found that about 0.67 million ha in the part of this area are damaged by excess of soluble salts, exchangeable sodium accumulation and water logging conditions to an degree that causes crop yield reduction (El-Mouhamady et al., 2010), and is characterized as salinesodic soils. The increase of salinity in soils and groundwater is a major concern in Egyptian agriculture as a result of poor drainage, especially, through flooding irrigation system (Mohamed et al., 2011).

The world's rice production has multiplied during the recent years, to a great extent because of the utilization of enhanced agricultural practices and high yielding genotypes. Rice (Oryza sativa L) is moderately sensitive crop to salinity, where is tolerant during germination turns out to be exceptionally delicate during the early seedling stage; gains tolerance vegetative development once more gets to be delicate through flowering and then turns out to be progressively more tolerant at maturity stage (El-Mouhamady et al., 2010 and Mansuri et al., 2012). The degree of salt tolerance depends on the types and concentration of salts, water regime, growth stage of the plant, duration of exposure to salt and rice genotypes. Genotypes rice is differentially influenced by salinity at various growth stages which the response to salinity certainly varies from growth stage to another (Sankar et al., 2011 and Aref and Rad, 2012). Growth and yield components of rice genotypes were severely affected by salinity as mentioned by Zayed et al. (2005 and 2014), Mohammadi et al. (2010) and Mansuri et al. (2012). One strategy to overcome the problem of salinity is selecting salt tolerant genotypes (Torabi, 2014). Understanding the genetic architecture of each breeding materials is a great interest for selecting the most desirable genotypes, in order to establish the most efficient breeding program for obtaining quick and maximum genetic improvement (ElMouhamady et al., 2010). The other main objective of any plant breeding programs is the development of genotype which consistently shows superior performance over stress of environments. However, 
genotype-environment interaction usually hampers selection of such genotype due to the failure of genotype to show the same characteristic in different environment, since the environmental factors are usually in continuous state of change in both space and time. The understanding of genotype and environment interaction in plant breeding is a matter of major importance (Hammoud and Gabr, 2014 and Al-Salim et al., 2016).

The objectives of this study is to 1) investigate the performance of the several rice genotypes under different salinity levels by defining the difference in the morphological and yield traits among genotypes, 2) estimate phenotypic and genotypic coefficients of variability and broad sense heritability for all studied traits under salinity conditions.

\section{MATERIALS AND METHODS \\ 1. Plant materials and \\ experimental design}

This investigation was carried out at the Experimental Farm of El-Sirw Station, Damietta governorate, Egypt, to investigate the performance of twelve rice genotypes grown under two soil salinity levels (ECe, i.e. 6.0 and $11.0 \mathrm{dS} \mathrm{m}^{-1}$ ) during the summer growing seasons of 2014 and 2015. The area is directly at sea level and is situated at latitude of $31^{\circ} 14^{\prime} \mathrm{N}$ and the longitude of $29^{\circ}$ $15^{\prime} \mathrm{E}$. The northeastern boundary is about 1 $\mathrm{km}$ from El-Manzala Lake (salty lake). The main characteristics of the site are long dry summer and rarely winter rainfall. The annual precipitation ranged from 0 to 100 $\mathrm{mm}$ a year. Twelve rice genotypes were used to establish the genetic materials in this study. The genotypes were assessed with two soil salinity levels (ECe: 6.0 and $11.0 \mathrm{dS} \mathrm{m}^{-1}$ ) measured at the beginning of seasons. The water irrigation used in that experiment during the growing seasons was obtained from El-Harrna drain with salinity level (ECw $1.60 \mathrm{dS} \quad \mathrm{m}^{-1}$ ). The field experiment was designed in a split plot design with three replications. The soil salinity levels were arranged at random in the main plots, while the rice genotypes were assigned at random in the sub-plots. Soil samples were taken randomly from different sites of the experimental area before beginning the experiments. The mechanical and chemical analysis of the soil during the two growing seasons are presented in Table (1) according to the methods of Chapman and Pratt (1961) and Black et al. (1965). The details of the twelve rice genotypes are presented in Table (2).

\section{Crop management}

The different cultural practices of rice nursery were followed according to the recommendations of Rice Research and Training Center, Agricultural Research Center, Egypt. The nursery cultivation was conducted under soil salinity of $4 \mathrm{dS} \mathrm{m}^{-1}$ and using irrigation water with salinity of $1.60 \mathrm{dS}$ $\mathrm{m}^{-1}$. Soil was plowed thoroughly and dry leveled. The experiments were done in the same salinity sites during the two growing seasons. The area of sub plot was $20 \mathrm{~m}^{2}$ (4 $x 5 \mathrm{~m})$. Nitrogen fertilizer (165 kg N ha ${ }^{-1}$ ) in the form of urea was splitting into equal three doses at 15 days after transplanting (DAT), 30 DAT and 45 DAT. Phosphorus (37 $\mathrm{kg} \mathrm{P}_{2} \mathrm{O}_{5} \mathrm{ha}^{-1}$ ) in the form of calcium super phosphate was added as one dose prior to the tillage. However, Zinc as $\mathrm{Zn} \mathrm{SO}_{4}^{-2}$ was applied after pudding. Rice genotypes were planted in May $3^{\text {th }}$ and $4^{\text {th }}$ in the first and second seasons, respectively. Plants transplanted after 30 days from sowing in both seasons at the rate of 3 seedlings per hill for each rice genotype with spacing of 20 between rows and $15 \mathrm{~cm}$ between hills.

\section{Measurements}

At the beginning of heading stage for each rice genotype, samples were taken, transferred to the lab and well prepared to determine growth characters (leaf area index, dry matter production g.m ${ }^{-2}$, total chlorophyll content), leaf chemical constituents (proline content, sodium $\mathrm{Na}^{+}$ 
and potassium $\mathrm{K}^{+}$as well as $\mathrm{Na}^{+} / \mathrm{K}^{+}$ratio). Leaf area index (LAI) was measured according to Yoshida et al. (1976). Total chlorophyll content in leaves was measured by SPAD meter. Proline content was assayed in fresh leaf according to Bates et al. (1973). Sodium and potassium leaf content were measured by flame photometer according to Wolf (1982).

Table (1). Mechanical and chemical analysis of the two experimental sites at El Sirw Station as an average of the two seasons.

\begin{tabular}{|c|c|c|c|c|c|c|c|c|c|c|c|}
\hline \multirow{2}{*}{$\begin{array}{c}\text { Salinity } \\
\text { Site }\end{array}$} & \multirow{2}{*}{$\begin{array}{c}\text { Soil } \\
\text { Texture }\end{array}$} & \multirow{2}{*}{$\mathrm{pH}$} & \multirow{2}{*}{$\begin{array}{c}\mathrm{ECe} \\
\mathrm{dSm}{ }^{-1}\end{array}$} & \multirow{2}{*}{$\begin{array}{c}\mathrm{CaCo}_{3} \\
\%\end{array}$} & \multicolumn{4}{|c|}{ Cation meq $\mathrm{L}^{-1}$} & \multicolumn{3}{|c|}{ Anion meq $\mathrm{L}^{-1}$} \\
\hline & & & & & $\mathrm{Ca}^{++}$ & $\mathrm{Mg}^{++}$ & $\mathrm{Na}^{+}$ & $\mathrm{K}^{+}$ & $\mathrm{SO}_{4}^{-}$ & $\mathrm{Cl}^{-}$ & $\mathrm{HCO}_{3}^{-}$ \\
\hline S1 & Clay & 8.2 & 6.0 & 0.43 & 5.3 & 10.5 & 45.0 & 0.46 & 19.8 & 35.1 & 5.1 \\
\hline S2 & Clay & 8.3 & 11.0 & 0.73 & 7.8 & 12.5 & 95.1 & 0.75 & 18.0 & 88.2 & 11.1 \\
\hline
\end{tabular}

Table (2). Pedigree and characteristics of the tested rice genotypes.

\begin{tabular}{|l|l|l|l|}
\hline No. & \multicolumn{1}{|c|}{ Genotypes } & \multicolumn{1}{|c|}{ Pedigree } & \multicolumn{1}{c|}{ Characteristics } \\
\hline 1 & Giza 177 & (Giza 171/Yomji No1) Pi No.4 & $\begin{array}{l}\text { Japonica type, early maturing } \\
\text { and short grain }\end{array}$ \\
\hline 2 & Giza 179 & GZ 1368-5-S-4 / GZ 6296 & $\begin{array}{l}\text { Indica/ Japonica type, very } \\
\text { early and short grain }\end{array}$ \\
\hline 3 & Giza 182 & (Giza181/IR 39422) Giza181 & $\begin{array}{l}\text { Indica type, medium maturing } \\
\text { and long grain }\end{array}$ \\
\hline 4 & Egyptian Jasmine & IR 262/ KDML105 & $\begin{array}{l}\text { Japonica type, early maturing } \\
\text { and short grain }\end{array}$ \\
\hline 5 & GZ 10303 & GZ7768/Yashira/Mochi & $\begin{array}{l}\text { Indica type, late maturing } \\
\text { and long grain }\end{array}$ \\
\hline 6 & GZ 10305 & GZ7768/ Mlayang95 & $\begin{array}{l}\text { Indica type, late maturing } \\
\text { and long grain }\end{array}$ \\
\hline 7 & IET 1444 & TNI/ CO.29 & $\begin{array}{l}\text { Indica type, medium maturing } \\
\text { and long grain }\end{array}$ \\
\hline 8 & GZ 10286 & Giza 177 / GZ 1368 & $\begin{array}{l}\text { Indica type, medium maturing } \\
\text { and short grain }\end{array}$ \\
\hline 9 & GZ 9399 & Giza 178/ IR 65844 & $\begin{array}{l}\text { Indica / japonica type, early } \\
\text { maturing and short grain }\end{array}$ \\
\hline 10 & GZ 9461 & Dany2Peyo / GZ6296 & $\begin{array}{l}\text { Indica/ japonica type, early } \\
\text { maturing and short grain }\end{array}$ \\
\hline 11 & PLGF 101 & Sakha101 / IR ET112 & $\begin{array}{l}\text { Japonica type, early maturing } \\
\text { and short grain }\end{array}$ \\
\hline 12 & Egyptian hybrid 1 & IR 69625A /Giza178 & $\begin{array}{l}\text { Indica type, medium maturing } \\
\text { and medium grain }\end{array}$ \\
\hline
\end{tabular}


Days to $50 \%$ heading was recorded according to Yoshida et al. (1976). The central area $\left(2 \mathrm{~m}^{2}\right)$ of each plot was manually harvested at maturity to estimate the yield and its related and components traits i.e. plant height $(\mathrm{cm})$, number of tillers per hill, number of panicles per hill, panicle length $(\mathrm{cm})$, number of filled grains per panicle, number of unfilled grains per panicle, 1000-grain weight (g.) and grain and biological yields (ton ha ${ }^{-1}$ ) were recorded. Harvest index was calculated as a ratio of grain yield to biological yield.

Combined analysis of variance for the two seasons was used (after performance homogeneity test) to test the interaction of different genetic components with the two environments. Genotypic variance $\left(\sigma^{2} g\right)$, environmental variance $\left(\sigma^{2} e\right)$, phenotypic variance $\left(\sigma^{2} \mathrm{ph}\right)$, genotypic (GCV) and phenotypic (PCV) coefficient of variability and heritability in broad sense $\left(\mathrm{H}^{2} \%\right)$ were estimated according to the formulas mentioned by Burton (1952), Johnson et al. (1955), Falconer and Mackay (1996) and Allard (1999) as follows:

- Genotypic variance $\left(\sigma^{2} g\right)$

Where:

$$
\left(\sigma^{2} \mathrm{~g}\right)=\frac{M 1-M 2}{r y}
$$

$\mathrm{M} 1=$ Mean squares due to genotypes.

M2=Mean square due to Error.

$r=$ Number of replications.

$y=$ years number

- Phenotypic variance $\left(\sigma^{2} \mathrm{ph}\right)$

$\sigma^{2} \mathrm{ph}=\sigma^{2} \mathrm{~g}+\sigma^{2} e$

Where: $\sigma^{2} \mathrm{e}=$ Environmental variance (M2)

- Genotypic coefficient of variability (GCV)

$$
\mathrm{GCV}=\frac{\sqrt{\sigma^{2} g}}{\bar{x}} X 100
$$

- Phenotypic coefficient of variability (PCV)

$$
\mathrm{PCV}=\frac{\sqrt{\sigma^{2} p h}}{\bar{x}} X 100
$$

- Heritability in broad sense $\left(\mathrm{H}^{2} \%\right)$

$$
\mathrm{H}^{2} \%=\frac{\sigma^{2} g}{\sigma^{2} p h} X 100
$$

\subsection{Statistical analysis}

The data of the two seasons were analyzed by the analysis of variance using IRRISTAT software as described by Snedecor and Cochran (1980). Differences among treatments mean were compared by least significant difference (LSD) at $P<$ 0.05 .

\section{RESULTS AND DISCUSSIONS \\ 1. Growth characters}

The tested soil salinity levels, i.e. S1 $(6.0$ $\left.\mathrm{dS} \mathrm{m}^{-1}\right)$ and S2 (11.0 dS $\left.\mathrm{m}^{-1}\right)$ had significant effect on the rice growth (leaf area index, dry mater production and total chlorophyll content) in the two seasons (Table 3). All growth characters were restricted under increasing salinity. Furthermore, the high salinity level (S2) sharply decreased the rice growth comparing to that obtained from medium salinity level (S1). This reduction was amounted to $26.71,18.8$ and $9.67 \%$ for LAI, dry matter production and chlorophyll content, respectively as an average of both seasons. This reduction could be discussed on the basis that salinity stress delayed phenological growth stages. High osmotic potential and diminished water accessibility to plants grown under high salinity result in cell membrane dehydration and lessening the permeability of $\mathrm{CO}_{2}$ and subsequently photosynthetic electron transport diminishes via of shrinkage of intercellular spaces (Torabi, 2014). Ion uptake and compartmentalization are crucial not only for normal growth but also for growth under salinity condition because the stress disturbs ion homeostasis. Increasing salinity induced ion imbalance and ion toxicity inside the plant cell. Salt accumulation inside cytoplasm of plant cell might be restricted the enzyme activities, hormones and growth regulators resulted in poor growth (Zeng et al., 2003; Tavakkoli et al., 2011 and Zayed et al., 2014).

Tested rice genotypes showed spectrum variation in the growth characters studied (LAl, dry matter and chlorophyll content) in 
Zayed et al.,

both season (Table 3). Furthermore, PLGF 101 and GZ 10305 genotypes gave the lowest values of leaf area index and chlorophyll content, respectively in both seasons. GZ 10303 genotype gave the lowest dry matter. Egyptian Hybrid 1 synthesized maximum amount of dry matter, leaf area index and chlorophyll content in both seasons. Among the promising rice genotypes, GZ 9399 and GZ 9461 were the most promise genotypes under both salinity levels regarding rice growth. The differences in dry matter production due to genotypes could be attributed to their differences in leaf area index and chlorophyll content. This was expected because of the differences between these genotypes in respective of their genetic background. The differences between genotypes were previously reported by Ali et al. (2014) and De Leon et al. (2015).

Table (3). Growth characters of rice as affected by salinity levels, genotypes and their interactions during 2014 and 2015 seasons.

\begin{tabular}{|c|c|c|c|c|c|c|c|c|c|}
\hline Characters & \multicolumn{3}{|c|}{ LAI } & \multicolumn{3}{|c|}{ Dry matter $\left(\mathrm{g} . / \mathrm{m}^{2}\right)$} & \multicolumn{3}{|c|}{$\begin{array}{l}\text { Total chlorophyll } \\
\text { (SPAD value) }\end{array}$} \\
\hline Salinity (S) & $\begin{array}{c}6 \\
d \mathrm{SSm}^{-1} \\
\end{array}$ & $\begin{array}{c}11 \\
\mathrm{dSm}^{-1}\end{array}$ & Mean & $\begin{array}{c}6 \\
d S^{-1}\end{array}$ & $\begin{array}{c}11 \\
\mathrm{dSm}^{-1} \\
\end{array}$ & Mean & $\begin{array}{c}6 \\
\mathrm{dSm}^{-1}\end{array}$ & $\begin{array}{c}11 \\
\mathrm{dSm}^{-1}\end{array}$ & Mean \\
\hline Genotypes & \multicolumn{9}{|c|}{2014 season } \\
\hline Giza 177 & 3.46 & 1.45 & 2.46 & 685.7 & 485.2 & 585.5 & 39.23 & 33.31 & 36.27 \\
\hline Giza 179 & 5.16 & 4.16 & 4.66 & 1121.8 & 993.3 & 1057.6 & 41.40 & 37.32 & 39.26 \\
\hline Giza 182 & 4.06 & 3.06 & 3.56 & 650.4 & 450.5 & 550.5 & 38.23 & 34.66 & 36.45 \\
\hline Egy. & 4.60 & 3.60 & 4.10 & 710.6 & 510.2 & 610.4 & 43.43 & 38.13 & 40.78 \\
\hline GZ 10303 & 3.10 & 2.40 & 2.75 & 638.3 & 438.3 & 538.3 & 36.66 & 32.66 & 34.66 \\
\hline GZ 10305 & 3.20 & 1.86 & 2.53 & 610.2 & 426.6 & 518.4 & 37.40 & 34.33 & 35.86 \\
\hline IET 1444 & 5.13 & 4.13 & 4.63 & 1190.8 & 1030.4 & 1110.6 & 41.66 & 36.33 & 39.00 \\
\hline GZ 10286 & 4.30 & 2.63 & 3.47 & 760.7 & 560.7 & 660.7 & 40.66 & 37.86 & 39.26 \\
\hline GZ 9399 & 5.40 & 4.40 & 4.90 & 1176.6 & 1060.5 & 1118.6 & 42.66 & 39.66 & 41.16 \\
\hline GZ 9461 & 5.23 & 4.23 & 4.73 & 1190.9 & 1036.6 & 1113.8 & 42.33 & 38.33 & 40.33 \\
\hline PLGF 101 & 3.23 & 1.47 & 2.35 & 723.3 & 523.3 & 623.3 & 38.66 & 32.76 & 35.71 \\
\hline Egy. Hybrid & 6.03 & 5.33 & 5.68 & 1383.5 & 1283.3 & 1333.4 & 43.31 & 43.36 & 43.34 \\
\hline Mean & 4.41 & 3.23 & & 903.6 & 733.2 & & 40.47 & 36.56 & \\
\hline $\begin{array}{r}\text { LSD } 0.05 \mathrm{~S} \\
\mathrm{G} \\
\text { SG }\end{array}$ & \multicolumn{3}{|c|}{$\begin{array}{l}0.31 \\
0.25 \\
0.43\end{array}$} & \multicolumn{3}{|c|}{$\begin{array}{l}38.57 \\
28.36 \\
48.77 \\
\end{array}$} & \multicolumn{3}{|c|}{$\begin{array}{l}1.09 \\
0.95 \\
1.64\end{array}$} \\
\hline & \multicolumn{9}{|c|}{2015 season } \\
\hline Giza 177 & 3.80 & 1.62 & 2.71 & 753.5 & 533.5 & 643.5 & 38.84 & 33.00 & 35.92 \\
\hline Giza 179 & 5.67 & 4.56 & 5.12 & 1233.8 & 1092.6 & 1163.2 & 40.98 & 36.96 & 38.97 \\
\hline Giza 182 & 4.46 & 3.36 & 3.91 & 715.2 & 495.0 & 605.1 & 37.85 & 34.32 & 36.09 \\
\hline Egy. & 5.05 & 3.95 & 4.50 & 781.6 & 561.2 & 671.4 & 42.99 & 37.75 & 40.37 \\
\hline GZ 10303 & 3.40 & 2.63 & 3.01 & 702.1 & 482.1 & 592.1 & 36.30 & 32.34 & 34.32 \\
\hline GZ 10305 & 3.51 & 2.05 & 2.78 & 671.7 & 469.3 & 570.5 & 37.02 & 33.99 & 35.50 \\
\hline IET 1444 & 5.63 & 4.53 & 5.08 & 1309.2 & 1133.0 & 1221.1 & 41.25 & 35.97 & 38.61 \\
\hline GZ 10286 & 4.72 & 2.89 & 3.81 & 836.3 & 616.1 & 726.2 & 40.26 & 37.48 & 38.87 \\
\hline GZ 9399 & 5.93 & 4.83 & 5.38 & 1294.3 & 1166.5 & 1230.4 & 42.24 & 39.27 & 40.76 \\
\hline GZ 9461 & 5.74 & 4.64 & 5.19 & 1309.5 & 1140.3 & 1224.9 & 41.91 & 37.95 & 39.93 \\
\hline PLGF 101 & 3.54 & 1.61 & 2.58 & 795.6 & 575.6 & 685.6 & 38.28 & 32.43 & 35.36 \\
\hline Egy. Hybrid & 6.62 & 5.85 & 6.24 & 1521.8 & 1411.5 & 1466.7 & 42.90 & 42.93 & 42.92 \\
\hline Mean & 4.84 & 3.54 & & 993.7 & 806.4 & & 40.07 & 36.19 & \\
\hline $\begin{array}{r}\text { LSD } 0.05 \mathrm{~S} \\
\mathrm{G} \\
\mathrm{SG}\end{array}$ & \multicolumn{3}{|c|}{$\begin{array}{l}0.38 \\
0.29\end{array}$} & \multicolumn{3}{|c|}{$\begin{array}{l}35.09 \\
31.20 \\
53.98\end{array}$} & \multicolumn{3}{|c|}{$\begin{array}{l}1.41 \\
1.17 \\
2.02\end{array}$} \\
\hline
\end{tabular}


The interaction between rice genotypes and levels of salinity significantly affected leaf area index, dry matter production and chlorophyll content (Table 3). Genotypes varied significantly under salinity levels for all growth traits, suggesting that increasing salinity is more likely controlled the shoot growth. The results show that LAI was gradually decreased with increasing salinity especially for Giza 177, PLGF 101 and GZ 10305 genotypes which have the lowest values in both seasons. On the other hand, the minimum values of dry matter and chlorophyll were achieved by planting $G Z$ 10305 and GZ 10303 genotypes, respectively under high salinity level. Egyptian Hybrid 1 variety had the highest values of $L A I$ and dry matter production but exhibited the second mean performance for chlorophyll after Egyptian Jasmine under medium salinity level. The highest reduction in dry matter production due to increasing salinity level from medium to high was recorded by GZ 10303 genotype which was amounted to $31.33 \%$ in both seasons, while the lowest reduction was obtained by sowing Egyptian Hybrid 1 which was $7.25 \%$, as an average of both growing seasons. These results are in line with those obtained by Zeng et al. (2003) and Mansuri et al. (2012).

\section{Leaf chemical constituents}

The data in Table (4) show that increasing salinity levels significantly increased leaf chemical constituents (proline content, $\mathrm{Na}^{+} \%$ and $\mathrm{Na}^{+} / \mathrm{K}^{+}$ratio) but reduced $\mathrm{K}^{+} \%$ in rice leaves. Increasing $\mathrm{Na}$ uptake against $\mathrm{K}$ uptake developed ion toxicity and imbalance resulted enzyme activity and metabolism disturbance inside plant cell resulted in more negative water potentials and growth restriction. Other researchers reported that increased salt concentration in root zone of plants causes accumulation of $\mathrm{Na}^{+}$and $\mathrm{Cl}^{-}$in shoot tissues and decline $\mathrm{Ca}^{+2}, \mathrm{~K}^{+}$and $\mathrm{Mg}^{+2}$ levels (Ramezani et al., 2011 and De Leon et al., 2015).
Rice genotypes significantly varied in their proline, $\mathrm{Na}^{+}, \mathrm{K}^{+}$and $\mathrm{Na}^{+} / \mathrm{K}^{+}$leaf contents in both seasons (Table 4). The most salt sensitive rice genotypes, Giza 177, GZ 10303, GZ 10305 and PLGF 101 failed to exert sufficient proline content to cope with salinity harmful, since they had lowest values of proline and potassium leaf content and the highest values of sodium and $\mathrm{Na}^{+} / \mathrm{K}^{+}$ ratio. Giza182 and GZ 10286 recorded medium level of proline, sodium, potassium and $\mathrm{Na}^{+} / \mathrm{K}^{+}$ratio. Egyptian Hybrid 1 recorded higher proline and potassium leaf contents and lower $\mathrm{Na}^{+} / \mathrm{K}^{+}$ratio in both seasons. The two promising rice genotypes, GZ 9399 and GZ 9461 showed reasonable proline content to occupy the second rank after both Egyptian Hybrid 1 and Giza 179 without significant level with Egyptian Jasmine. Salt tolerant genotypes maintained high concentrations of $\mathrm{K}^{+}$and low concentrations of $\mathrm{Na}^{+}$in leaf to avoid their deleterious effect on functional macromolecules in plant cell (Zayed et al. 2014). In this concern, ElMouhamady et al. (2010) stated that there bands were found to be index and marker for salinity tolerance in rice genotypes by increasing $\mathrm{K}^{+}$content and decreasing of $\mathrm{Na}^{+}$ content.

The interaction between rice genotypes and levels of salinity significantly affected proline content, $\mathrm{Na}^{+}, \mathrm{K}^{+}$leaf content and $\mathrm{Na}^{+} / \mathrm{K}^{+}$ratio (Table 4). Egyptian Hybrid 1 surpassed other genotypes and possessed their higher mean values of proline content and $\mathrm{K}^{+} \%$ when it was planted under high and medium salinity levels, respectively for such traits while, Egyptian Jasmine had the higher values of $\mathrm{Na}^{+} \%$ when it was planted under high salinity level followed by Giza 182 genotypes. However, GZ 10303 genotype recorded the highest $\mathrm{Na}^{+} / \mathrm{K}^{+}$ratio under high salinity level comparing with other genotypes. On the other side, the lowest values of proline content and $\mathrm{K}^{+} \%$ were achieved under high salinity level by GZ 10305 and GZ 10303 genotypes, respectively. There are differences amongst 
Zayed et al.,

tolerant and sensitive genotypes regarding compartmentalization of salt. The sensitive genotypes can't compartmentalize salt in vacuoles and the salts collect quickly in cytoplasm and in this manner the photosynthesis and absorption is lessened but in tolerant genotypes the salt is quickly compartmentalized in vacuoles and the vital actions change slowly (Torabi, 2014). These findings were in conformity with that reported by El-Mouhamady et al. (2010) and De Leon et al. (2015).

Table (4). Leaf chemical constituents of rice as affected by salinity levels, genotypes and their interactions during 2014 and 2015 seasons.

\begin{tabular}{|c|c|c|c|c|c|c|c|c|c|c|c|c|}
\hline Characters & \multicolumn{3}{|c|}{ Proline $(\mu \mathrm{g} / \mathrm{g} \mathrm{fWt})$} & \multicolumn{3}{|c|}{$\mathrm{Na}^{+}(\%)$} & \multicolumn{3}{|c|}{$\mathrm{K}^{+}(\%)$} & \multicolumn{3}{|c|}{$\mathrm{Na}^{+} / \mathrm{k}^{+}$(ratio) } \\
\hline Salinity (S) & $\mathrm{dSm}^{-1}$ & $\begin{array}{c}11 \\
\mathrm{dSm}^{-1}\end{array}$ & Mean & $\begin{array}{c}6 \\
\mathrm{dSm}\end{array}$ & $\begin{array}{c}11 \\
\mathrm{dSm}^{-1}\end{array}$ & Mean & $\mathrm{dSm}^{-1}$ & $\begin{array}{c}11 \\
\mathrm{dSm}^{-1}\end{array}$ & Mean & $\mathrm{dSm}^{-1}$ & $\begin{array}{c}11 \\
\mathrm{dSm}^{-1}\end{array}$ & Mean \\
\hline Genotypes(G) & \multicolumn{12}{|c|}{2014 season } \\
\hline Giza 177 & 4.10 & 4.66 & 4.38 & 2.03 & 2.60 & 2.31 & 1.30 & 0.99 & 1.15 & 1.56 & 2.63 & 2.01 \\
\hline Giza 179 & 13.08 & 17.02 & 15.05 & 1.40 & 1.63 & 1.51 & 1.86 & 1.50 & 1.68 & 0.75 & 1.09 & 0.90 \\
\hline Giza 182 & 6.03 & 8.63 & 7.33 & 1.80 & 2.80 & 2.30 & 1.53 & 1.10 & 1.32 & 1.18 & 2.55 & 1.74 \\
\hline Egy. Jasmine & 12.30 & 15.03 & 13.67 & 1.60 & 2.95 & 2.27 & 1.60 & 1.40 & 1.50 & 1.00 & 2.11 & 1.51 \\
\hline GZ 10303 & 6.20 & 4.02 & 5.11 & 2.10 & 2.60 & 2.35 & 1.23 & 0.98 & 1.11 & 1.71 & 2.65 & 2.12 \\
\hline GZ 10305 & 6.07 & 3.23 & 4.65 & 2.02 & 2.62 & 2.32 & 1.26 & 1.13 & 1.20 & 1.60 & 2.32 & 1.93 \\
\hline IET 1444 & 15.68 & 17.64 & 16.66 & 1.36 & 1.70 & 1.53 & 1.83 & 1.36 & 1.60 & 0.74 & 1.25 & 0.96 \\
\hline GZ 10286 & 8.61 & 10.66 & 9.64 & 1.83 & 2.38 & 2.10 & 1.50 & 1.06 & 1.28 & 1.22 & 2.25 & 1.64 \\
\hline GZ 9399 & 13.31 & 16.03 & 14.67 & 1.26 & 1.66 & 1.46 & 1.76 & 1.30 & 1.53 & 0.72 & 1.28 & 0.95 \\
\hline GZ 9461 & 13.01 & 14.33 & 13.67 & 1.46 & 1.60 & 1.54 & 1.76 & 1.23 & 1.50 & 0.83 & 1.30 & 1.02 \\
\hline PLGF 101 & 5.33 & 5.00 & 5.17 & 1.99 & 2.43 & 2.21 & 1.23 & 1.05 & 1.14 & 1.62 & 2.31 & 1.94 \\
\hline Egy. Hybrid 1 & 16.11 & 18.64 & 17.38 & 1.53 & 2.01 & 1.77 & 2.16 & 1.79 & 1.98 & 0.71 & 1.14 & 0.89 \\
\hline Mean & 9.99 & 11.24 & & 1.70 & 2.25 & & 1.59 & 1.24 & & 1.07 & 1.81 & \\
\hline \multirow[t]{2}{*}{$\begin{array}{rr}\text { LSD } 0.05 \text { S } \\
\text { G } \\
\text { SG }\end{array}$} & \multicolumn{3}{|c|}{$\begin{array}{l}1.05 \\
1.02 \\
1.75\end{array}$} & \multicolumn{3}{|c|}{$\begin{array}{l}0.22 \\
0.19 \\
0.33\end{array}$} & \multicolumn{3}{|c|}{$\begin{array}{l}0.21 \\
0.23 \\
0.40\end{array}$} & \multicolumn{3}{|c|}{$\begin{array}{l}0.16 \\
0.12 \\
0.21\end{array}$} \\
\hline & \multicolumn{12}{|c|}{2015 season } \\
\hline Giza 177 & 4.33 & 5.04 & 4.68 & 2.15 & 2.75 & 2.45 & 1.50 & 1.09 & 1.30 & 1.43 & 2.52 & 1.88 \\
\hline Giza 179 & 14.04 & 18.26 & 16.15 & 1.48 & 1.73 & 1.61 & 2.05 & 1.65 & 1.85 & 0.72 & 1.05 & 0.87 \\
\hline Giza 182 & 6.48 & 9.36 & 7.92 & 1.90 & 2.96 & 2.43 & 1.68 & 1.21 & 1.45 & 1.13 & 2.45 & 1.68 \\
\hline Egy. Jasmine & 12.96 & 16.56 & 14.76 & 1.69 & 3.13 & 2.41 & 1.76 & 1.54 & 1.65 & 0.96 & 2.03 & .46 \\
\hline GZ 10303 & 6.48 & 4.32 & 5.40 & 2.22 & 2.75 & 2.49 & 1.35 & 1.08 & 1.22 & 1.64 & 2.55 & 2.04 \\
\hline GZ 10305 & 6.40 & 3.60 & 5.00 & 2.15 & 2.78 & 2.47 & 1.39 & 1.24 & 1.31 & 1.55 & 2.24 & 1.89 \\
\hline IET 1444 & 16.9 & 19.08 & 17.99 & 1.44 & 1.80 & 1.62 & 2.01 & 1.50 & 1.76 & 0.72 & 1.20 & 0.92 \\
\hline GZ 10286 & 9.36 & 11.52 & 10.44 & 1.94 & 2.52 & 2.23 & 1.60 & 1.17 & 1.39 & 1.21 & 2.15 & 1.60 \\
\hline GZ 9399 & 14.40 & 17.28 & 15.84 & 1.34 & 1.76 & 1.55 & 1.94 & 1.43 & 1.68 & 0.69 & 1.23 & 0.92 \\
\hline GZ 9461 & 14.02 & 15.48 & 14.75 & 1.55 & 1.69 & 1.61 & 1.94 & 1.35 & 1.65 & 0.80 & 1.25 & 0.98 \\
\hline PLGF 101 & 5.76 & 5.40 & 5.58 & 2.11 & 2.57 & 2.34 & 1.35 & 1.15 & 1.25 & 1.56 & 2.23 & 1.87 \\
\hline Egy. Hybrid 1 & 18.05 & 20.16 & 19.11 & 1.62 & 2.14 & 1.88 & 2.38 & 1.94 & 2.16 & 0.68 & 1.10 & 0.87 \\
\hline Mean & 10.76 & 12.17 & & 1.80 & 2.38 & & 1.75 & 1.36 & & 1.03 & 1.75 & \\
\hline $\begin{array}{r}\text { LSD } 0.05 \text { S } \\
\text { G } \\
\text { SG }\end{array}$ & & $\begin{array}{l}1.23 \\
1.54 \\
2.66\end{array}$ & & & $\begin{array}{l}0.39 \\
0.31 \\
0.54\end{array}$ & & & $\begin{array}{l}0.18 \\
0.15 \\
0.26\end{array}$ & & & $\begin{array}{l}0.12 \\
0.09 \\
0.16\end{array}$ & \\
\hline
\end{tabular}




\section{Yield and related traits}

The obtained data showed that the tested soil salinity levels had significant effect on the yield and yield attributes and components of rice, i.e. heading date, plant height, tillers number hill $^{-1}$ and panicles number hill ${ }^{-1}$ (Table 5), panicle length, filled grains panicle ${ }^{-1}$, unfilled grains panicle ${ }^{-1}$ and 1000-grain weight (Table 6) and grain yield $\mathrm{ha}^{-1}$, biological yield $\mathrm{ha}^{-1}$ and harvest index (Table 7). Data in Table (5) declare that increasing salinity from medium to high level significantly prolonged the days from sowing to heading in both growing seasons. The longest period for days to heading was obtained when rice plants were grown under high salinity level with delaying in the heading date by about $5.09 \%$ as an average of both seasons. This difference was attributed to the higher level of osmotic and ionic stresses imposed during the vegetative stage (Castillo et al. 2007). The prolonging heading date might be attributed to cycling of plant recovery after salt stress. Furthermore, salinity might disturb the developing of rice growth (Aref and Rad, 2012). The high salinity level markedly reduced plant height and number of tillers hill $^{-1}$ by 9.0 and $19.4 \%$, respectively as an average of both seasons. It is also reduced panicles number hill ${ }^{-1}$ in both of growing seasons with an average reduction reached about $26.8 \%$. It is being that salinity restricted tiller formation as a result of decreasing bud formation since the salinity hindered the early growth. The poor plant stand resulting from stress resulted in a marked reduction in panicles number since the most of energy used in recovery and fighting salt stress rather than developing fertile panicle. Similar trend was observed by Zeng et al. (2002).

Increasing salinity stress severely restricted panicle length, numbers of filled grains panicle ${ }^{-1}$ and 1000-grain weight but increased unfilled grains panicle $e^{-1}$ (Table 6). For instance, it is worthy to mention that panicle length contributed to the same pattern of plant height under various stresses. Stress conditions significantly magnified sterility. Panicle fertility is being affected more among the main yield components. On the other hand, 1000-grain weight was less affected by salt stress in comparing with number of filled grains per panicle. Increasing level of salinity affected filling rate of rice grains as a result of hindering current photosynthesis, shortening the active grain filling period, assimilates translocation as well as panicle exertion and pollination. Low panicle number and low panicle fertility might cause a reduction in the yield. Short panicles in this concern produced by high salinity level might attribute to reducing growth hormones and regulators formation which diminished the cell division and elongation (Hamayun et al., 2010).

Rice grain and biological yields as well as harvest index were significantly affected by both tested salinity levels (Table 7 ). By the way, high salinity level (11.0 dS $\left.\mathrm{m}^{-1}\right)$ significantly decreased the mean values of yield and harvest index by about 43.66, 33.81 and $18.7 \%$ for grain yield, biological yield and harvest index, respectively compared to the medium salinity level (6.0 $\mathrm{dS} \mathrm{m}^{-1}$ ) as an average of both seasons. This reduction may be due to that salinity affected cell elongation, cell membrane stability, cell division and cell enlargement as well as cell turgid. Generally, stresses of salinity affected tillers formation, panicle formation, photosynthesis rate, metabolic and assimilates processes, nutrient uptake, nutrient transportation between plant organs, and transformation of assimilates and solutes. These stresses might also have affected plant phonology and grain filling processes, resulting overall in poor plant populations, poor growth, poor yield attributes, high sterility and low filled grains panicle $^{-1}$ leading finally to low grain yield. Similar results were reported by Wanichananan et al. (2003) and ElMouhamady et al. (2010). 
Zayed et al.,

Table (5). Some yield attributes of rice as affected by salinity levels, genotypes and their interactions during 2014 and 2015 seasons.

\begin{tabular}{|c|c|c|c|c|c|c|c|c|c|c|c|c|}
\hline Characters & \multicolumn{3}{|c|}{ Heading date (day) } & \multicolumn{3}{|c|}{ Plant height (cm) } & \multicolumn{3}{|c|}{ Tillers number hill $^{-1}$} & \multicolumn{3}{|c|}{ Panicles number hill ${ }^{-1}$} \\
\hline Salinity (S) & $\begin{array}{c}6 \\
\mathrm{dSm}^{-1}\end{array}$ & $\begin{array}{c}11 \\
\mathrm{dSm}^{-1}\end{array}$ & Mean & $\begin{array}{c}6 \\
d S m^{-1}\end{array}$ & $\begin{array}{c}11 \\
\mathrm{dSm}^{-1}\end{array}$ & Mean & $\begin{array}{c}6 \\
\mathrm{dSm}^{-1}\end{array}$ & $\begin{array}{c}11 \\
\mathrm{dSm}^{-1}\end{array}$ & Mean & $\begin{array}{c}6 \\
\mathrm{dSm}^{-1}\end{array}$ & $\begin{array}{c}11 \\
\mathrm{dSm}^{-1}\end{array}$ & Mean \\
\hline Genotypes $(\mathrm{G})$ & \multicolumn{12}{|c|}{2014 season } \\
\hline Giza 177 & 86.25 & 89.75 & 88.00 & 79.2 & 72.50 & 75.85 & 14.25 & 10.33 & 12.29 & 11.25 & 7.42 & 9.34 \\
\hline Giza 179 & 92.33 & 103.25 & 97.79 & 80.33 & 74.65 & 77.49 & 20.42 & 14.50 & 17.46 & 18.33 & 13.75 & 16.04 \\
\hline Giza 182 & 11.00 & 116.33 & 113.67 & 81.25 & 71.80 & 76.53 & 17.08 & 12.42 & 14.75 & 14.75 & 11.08 & 12.92 \\
\hline Egy. Jasmine & 108.50 & 115.33 & 111.92 & 96.38 & 85.50 & 90.94 & 18.25 & 14.50 & 16.38 & 16.67 & 11.33 & 14.00 \\
\hline GZ 10303 & 11.33 & 114.75 & 113.04 & 73.27 & 65.58 & 69.43 & 14.92 & 12.67 & 13.80 & 11.42 & 8.25 & 9.84 \\
\hline GZ 10305 & 11.67 & 116.00 & 113.84 & 76.26 & 69.85 & 73.06 & 17.25 & 14.00 & 15.63 & 15.83 & 11.75 & 13.79 \\
\hline IET 1444 & 106.25 & 110.33 & 108.29 & 105.34 & 96.44 & 100.89 & 19.5 & 15.67 & 17.59 & 12.92 & 9.33 & 11.13 \\
\hline GZ 10286 & 98.75 & 105.75 & 102.25 & 103.6 & 97.12 & 100.36 & 19.92 & 16.25 & 18.09 & 17.25 & 14.08 & 15.67 \\
\hline GZ 9399 & 102.00 & 106.25 & 104.13 & 86.25 & 81.20 & 83.73 & 19.67 & 15.08 & 17.38 & 17.25 & 12.08 & 14.67 \\
\hline GZ 9461 & 100.67 & 104.50 & 102.59 & 81.45 & 74.20 & 77.83 & 17.25 & 14.25 & 15.75 & 15.92 & 11.75 & 13.84 \\
\hline PLGF 101 & 92.33 & 99.50 & 95.92 & 70.2 & 63.50 & 66.85 & 13.25 & 9.50 & 11.38 & 10.75 & 6.92 & 8.84 \\
\hline Egy. Hybrid 1 & 96.00 & 101.25 & 98.63 & 103.14 & 94.35 & 98.75 & 23.33 & 18.25 & 20.79 & 18.50 & 15.33 & 16.92 \\
\hline Mean & 101.63 & 107.17 & & 86.39 & 78.89 & & 17.92 & 13.95 & & 15.07 & 11.09 & \\
\hline $\begin{array}{r}\text { LSD } 0.05 \mathrm{~S} \\
\mathrm{G} \\
\mathrm{SG}\end{array}$ & & $\begin{array}{l}4.52 \\
4.14 \\
7.12\end{array}$ & & & $\begin{array}{c}9.47 \\
8.69 \\
15.03\end{array}$ & & & $\begin{array}{l}2.83 \\
2.07 \\
3.58\end{array}$ & & & $\begin{array}{l}3.38 \\
2.34 \\
4.04\end{array}$ & \\
\hline & \multicolumn{12}{|c|}{2015 season } \\
\hline Giza 177 & 87.42 & 93.50 & 90.46 & 76.25 & 67.82 & 72.04 & 12.42 & 10.67 & 11.55 & 10.67 & 6.92 & 8.80 \\
\hline Giza 179 & 96.33 & 102.67 & 99.50 & 78.65 & 70.51 & 74.58 & 19.83 & 17.25 & 18.54 & 16.25 & 13.33 & 14.79 \\
\hline Giza 182 & 111.33 & 114.25 & 112.79 & 83.62 & 77.52 & 80.57 & 14.75 & 12.33 & 13.54 & 13.58 & 10.08 & 11.83 \\
\hline Egy. Jasmine & 108.67 & 112.25 & 110.46 & 94.52 & 83.22 & 88.87 & 16.42 & 13.67 & 15.05 & 18.25 & 12.92 & 15.59 \\
\hline GZ 10303 & 106.08 & 112.50 & 109.29 & 69.97 & 64.87 & 67.42 & 13.25 & 10.67 & 11.96 & 13.08 & 8.00 & 10.54 \\
\hline GZ 10305 & 106.42 & 112.50 & & 81.67 & 72.87 & 77.27 & 18.33 & 14.83 & 16.58 & 14.75 & 10.33 & 12.54 \\
\hline IET 1444 & 104.75 & 108.33 & & 107.42 & 98.06 & & 16.50 & 13.75 & 15.13 & 15.42 & 10.75 & 13.09 \\
\hline GZ 10286 & 101.42 & 108.08 & 104.75 & 104.65 & 90.50 & 97.58 & 20.25 & 18.08 & 19.17 & 18.42 & 13.67 & 16.05 \\
\hline GZ 9399 & 99.67 & 105.67 & 102.67 & 85.25 & 77.52 & & 21.67 & 18.25 & 19.96 & 15.50 & 11.42 & 13.46 \\
\hline GZ 9461 & 100.42 & 106.08 & 103.25 & 81.98 & 78.08 & 80.03 & 15.67 & 11.75 & 13.71 & 13.75 & 9.83 & 11.79 \\
\hline PLGF 101 & 90.50 & 97.00 & 93.75 & 66.02 & 60.55 & 63.29 & 12.08 & 8.75 & 10.42 & 9.83 & 6.25 & 8.04 \\
\hline Egy. Hybrid 1 & 98.25 & 102.67 & 100.46 & 100.52 & 92.87 & 96.70 & 22.50 & 19.75 & 21.13 & 19.25 & 16.67 & 17.96 \\
\hline Mean & 100.94 & 106.29 & & 85.88 & 77.87 & & 16.97 & 14.15 & & 14.90 & 10.85 & \\
\hline LSD $0.05 \mathrm{~S}$ & & 3.89 & & & 8.18 & & & 3.70 & & & 2.60 & \\
\hline $\begin{array}{c}G \\
S G\end{array}$ & & $\begin{array}{l}3.55 \\
6.10\end{array}$ & & & $\begin{array}{c}6.46 \\
11.11\end{array}$ & & & $\begin{array}{l}2.86 \\
4.95\end{array}$ & & & $\begin{array}{l}2.08 \\
3.60\end{array}$ & \\
\hline
\end{tabular}


Zayed et al.,

Table (6). Yield components of rice as affected by salinity levels, genotypes and their interactions during 2014 and 2015 seasons.

\begin{tabular}{|c|c|c|c|c|c|c|c|c|c|c|c|c|}
\hline Characters & \multicolumn{3}{|c|}{ Panicle length $(\mathrm{cm})$} & \multicolumn{3}{|c|}{ Filled grains panicle $^{-1}$} & \multicolumn{3}{|c|}{ Unfilled grains panicle ${ }^{-1}$} & \multicolumn{3}{|c|}{ 1000-grain weight (g.) } \\
\hline Salinity (S) & $\begin{array}{c}6 \\
\mathrm{dSSm}^{-1}\end{array}$ & $\begin{array}{c}11 \\
\mathrm{dSSm}^{-1}\end{array}$ & Mean & $\begin{array}{c}6 \\
\mathrm{dSm}^{-1}\end{array}$ & $\begin{array}{c}11 \\
\mathrm{dSm}^{-1}\end{array}$ & Mean & $\begin{array}{c}6 \\
\mathrm{dSm}\end{array}$ & $\begin{array}{c}11 \\
\mathrm{dS} m^{-1}\end{array}$ & Mean & $\begin{array}{c}6 \\
\mathrm{dSSm}^{-1}\end{array}$ & $\begin{array}{c}11 \\
\mathrm{dSm}\end{array}$ & Mean \\
\hline Genotypes(G) & \multicolumn{12}{|c|}{2014 season } \\
\hline Giza 177 & 17.35 & 14.20 & 16.28 & 100.5 & 64.13 & \begin{tabular}{|l|}
82.32 \\
\end{tabular} & 28.93 & 56.33 & 42.63 & 25.76 & 21.16 & 23.46 \\
\hline Giza 179 & 17.82 & 16.20 & 17.01 & 116.6 & 81.1 & 98.85 & 9.80 & 20.33 & 15.07 & 24.30 & 21.93 & 23.11 \\
\hline Giza 182 & 19.49 & 16.23 & 17.36 & 115 & 67.33 & 91.17 & 16.50 & 28.00 & 22.25 & 20.33 & 18.66 & 19.50 \\
\hline Egy. Jasmine & 19.70 & 16.66 & 18.18 & 121 & 71.66 & 96.33 & 17.66 & 29.33 & 23.50 & 20.83 & 17.33 & 19.08 \\
\hline GZ 10303 & 18.86 & 16.36 & 17.61 & 98 & 51.66 & 74.83 & 32.00 & 60.00 & 46.00 & 23.33 & 22.33 & 22.83 \\
\hline GZ 10305 & 19.43 & 17.33 & 18.38 & 109.3 & 79.66 & 94.48 & 23.00 & 42.66 & 32.83 & 24.33 & 23.16 & 23.75 \\
\hline IET 1444 & 19.40 & 17.90 & 18.65 & 116 & 83.66 & 99.83 & 11.33 & 21.43 & 16.38 & 23.23 & 22.16 & 22.70 \\
\hline GZ 10286 & 20.66 & 18.56 & 19.61 & 127 & 101.3 & 114.15 & 19.00 & 27.00 & 23.00 & 24.33 & 23.20 & 23.76 \\
\hline GZ 9399 & 19.08 & 16.90 & 17.99 & 118.6 & 92 & 105.30 & 15.00 & 25.66 & 20.33 & 23.16 & 21.56 & 22.36 \\
\hline GZ 9461 & 17.54 & 17.30 & 17.42 & 116 & 88.66 & 102.33 & 15.25 & 29.00 & 22.13 & 23.50 & 22.00 & 22.75 \\
\hline PLGF 101 & 16.04 & 13.93 & 15.16 & 98.33 & 51 & 74.67 & 34.00 & 52.00 & 43.00 & 25.66 & 21.66 & 23.66 \\
\hline Egy. Hybrid 1 & 23.00 & 20.30 & 21.65 & 138.1 & 119.6 & 128.85 & 17.13 & 37.00 & 27.06 & 23.56 & 22.16 & 22.86 \\
\hline Mean & 19.03 & 16.82 & & 114.54 & 79.31 & & 19.97 & 35.73 & & 23.53 & 21.44 & \\
\hline $\begin{array}{r}\text { LSD } 0.05 \text { S } \\
\text { G } \\
\text { SG }\end{array}$ & & $\begin{array}{l}2.02 \\
1.19 \\
2.06\end{array}$ & & & $\begin{array}{c}8.27 \\
6.64 \\
11.48\end{array}$ & & & $\begin{array}{l}3.25 \\
2.65 \\
4.58\end{array}$ & & & $\begin{array}{l}1.02 \\
0.82 \\
1.42\end{array}$ & \\
\hline & \multicolumn{12}{|c|}{2015 season } \\
\hline Giza 177 & 17.20 & 15.06 & 15.63 & 97.92 & 61.83 & 79.88 & 31.53 & 61.63 & 46.58 & 25.58 & 20.02 & 22.80 \\
\hline Giza 179 & 17.66 & 16.05 & 16.86 & 111.08 & 80.67 & 95.88 & 11.76 & 21.06 & 16.41 & 24.13 & 23.76 & 23.95 \\
\hline Giza 182 & 18.32 & 16.08 & 17.20 & 119.42 & 69.92 & 94.67 & 18.00 & 30.53 & 24.26 & 20.19 & 18.53 & 19.36 \\
\hline Egy. Jasmine & 19.52 & 16.51 & 18.02 & 116.42 & 68.33 & 92.38 & 19.26 & 32.00 & 25.63 & 20.69 & 17.21 & 18.95 \\
\hline GZ 10303 & 18.69 & 16.21 & 17.45 & 97.58 & 57.33 & 77.46 & 34.90 & 65.40 & 50.15 & 23.17 & 22.17 & 22.67 \\
\hline GZ 10305 & 19.25 & 17.17 & 18.21 & 112.80 & 81.75 & 97.28 & 25.10 & 46.53 & 35.82 & 24.16 & 23.00 & 23.58 \\
\hline IET 1444 & 19.22 & 17.74 & 18.48 & 118.67 & 85.25 & 101.96 & 16.73 & 24.46 & 20.60 & 23.70 & 22.01 & 22.86 \\
\hline GZ 10286 & 20.48 & 18.40 & 19.44 & 126.42 & 98.8 & 112.61 & 19.80 & 28.50 & 24.15 & 24.16 & 23.04 & 23.60 \\
\hline GZ 9399 & 18.91 & 16.75 & 17.83 & 110.67 & 89.5 & 100.09 & 16.36 & 27.96 & 22.16 & 23.00 & 21.04 & 22.02 \\
\hline GZ 9461 & 17.38 & 17.14 & 17.26 & 113.42 & 85.42 & 99.42 & 17.43 & 31.60 & 24.51 & 23.33 & 21.84 & 22.59 \\
\hline PLGF 101 & 16.25 & 13.80 & 15.03 & 100.83 & 55.17 & 78.00 & 37.10 & 56.70 & 46.90 & 25.49 & 21.51 & 23.50 \\
\hline Egy. Hybrid 1 & 22.79 & 20.11 & 21.45 & 130.00 & 112.42 & 121.21 & 18.66 & 40.30 & 29.48 & 22.82 & 21.91 & 22.37 \\
\hline Mean & 18.81 & 16.75 & & 112.94 & 78.87 & & 22.22 & 38.89 & & 23.37 & 21.34 & \\
\hline LSD $0.05 \mathrm{~S}$ & & 1.75 & & & 10.05 & & & 4.46 & & & 1.18 & \\
\hline & & 1.28 & & & 8.66 & & & 4.19 & & & 1.06 & \\
\hline & & 2.21 & & & 14.99 & & & 7.25 & & & 1.83 & \\
\hline
\end{tabular}


Zayed et al.,

Table (7). Yields and harvest index of rice as affected by salinity, genotypes and their interactions during 2014 and 2015 seasons.

\begin{tabular}{|c|c|c|c|c|c|c|c|c|c|}
\hline Characters & \multicolumn{3}{|c|}{ Grain yield (ton ha ${ }^{-1}$ ) } & \multicolumn{3}{|c|}{ Biological yield (ton ha ${ }^{-1}$ ) } & \multicolumn{3}{|c|}{ Harvest index } \\
\hline Salinity (S) & $6 \mathrm{dSm}^{-1}$ & $11 \mathrm{dSm}^{-1}$ & Mean & $6 \mathrm{dSm}^{-1}$ & $11 \mathrm{dSm}^{-1}$ & Mean & $6 \mathrm{dSm}^{-1}$ & $11 \mathrm{dSm}^{-1}$ & Mean \\
\hline Genotypes(G) & \multicolumn{9}{|c|}{2014 season } \\
\hline Giza 177 & 3.23 & 1.10 & 2.17 & 9.45 & 4.96 & 7.21 & 0.342 & 0.222 & 0.282 \\
\hline Giza 179 & 6.78 & 4.60 & 5.69 & 14.00 & 10.33 & 12.17 & 0.484 & 0.445 & 0.465 \\
\hline Giza 182 & 4.23 & 1.45 & 2.84 & 11.03 & 5.61 & 8.32 & 0.383 & 0.258 & 0.321 \\
\hline Egy. Jasmine & 4.66 & 1.82 & 3.24 & 10.00 & 5.60 & 7.80 & 0.466 & 0.325 & 0.396 \\
\hline GZ 10303 & 3.11 & 1.30 & 2.21 & 8.16 & 5.53 & 6.85 & 0.381 & 0.235 & 0.308 \\
\hline GZ 10305 & 5.20 & 2.26 & 3.73 & 12.06 & 6.13 & 9.10 & 0.431 & 0.369 & 0.400 \\
\hline IET 1444 & 5.13 & 3.00 & 4.07 & 11.86 & 7.22 & 9.54 & 0.433 & 0.416 & 0.425 \\
\hline GZ 10286 & 6.08 & 3.16 & 4.62 & 16.06 & 12.60 & 14.33 & 0.379 & 0.251 & 0.315 \\
\hline GZ 9399 & 6.83 & 5.03 & 5.93 & 13.66 & 11.43 & 12.55 & 0.500 & 0.440 & 0.470 \\
\hline GZ 9461 & 6.30 & 3.53 & 4.92 & 13.96 & 8.90 & 11.43 & 0.451 & 0.397 & 0.424 \\
\hline PLGF 101 & 2.95 & 1.20 & 2.08 & 7.16 & 4.36 & 5.76 & 0.412 & 0.275 & 0.344 \\
\hline Egy. Hybrid 1 & 7.63 & 5.83 & 6.73 & 16.60 & 12.69 & 14.65 & 0.460 & 0.459 & 0.460 \\
\hline Mean & 5.18 & 2.86 & & 12.00 & 7.95 & & 0.427 & 0.341 & \\
\hline $\begin{array}{rr}\text { LSD } 0.05 \mathrm{~S} \\
\mathrm{G} \\
\mathrm{SG}\end{array}$ & \multicolumn{3}{|c|}{$\begin{array}{l}0.45 \\
0.77\end{array}$} & & $\begin{array}{l}1.43 \\
1.07 \\
1.85\end{array}$ & & & $\begin{array}{l}0.07 \\
0.06 \\
0.10\end{array}$ & \\
\hline & \multicolumn{9}{|c|}{2015 season } \\
\hline Giza 177 & 2.99 & 1.48 & 2.24 & 8.36 & 4.63 & 6.50 & 0.358 & 0.320 & 0.339 \\
\hline Giza 179 & 6.63 & 4.45 & 5.54 & 13.76 & 10.03 & 11.90 & 0.482 & 0.444 & 0.463 \\
\hline Giza 182 & 4.13 & 1.37 & 2.75 & 10.93 & 5.53 & 8.23 & 0.378 & 0.248 & 0.313 \\
\hline Egy. Jasmine & 4.53 & 1.81 & 3.17 & 9.90 & 5.50 & 7.70 & 0.458 & 0.329 & 0.394 \\
\hline GZ 10303 & 3.69 & 1.29 & 2.49 & 8.06 & 5.43 & 6.75 & 0.458 & 0.238 & 0.348 \\
\hline GZ 10305 & 5.16 & 2.25 & 3.71 & 11.91 & 6.03 & 8.97 & 0.433 & 0.373 & 0.403 \\
\hline IET 1444 & 5.10 & 2.98 & 4.04 & 11.76 & 7.11 & 9.44 & 0.434 & 0.419 & 0.427 \\
\hline GZ 10286 & 5.90 & 3.50 & 4.70 & 15.40 & 11.5 & 13.45 & 0.383 & 0.304 & 0.344 \\
\hline GZ 9399 & 6.79 & 5.51 & 6.15 & 13.65 & 11.33 & 12.49 & 0.497 & 0.486 & 0.492 \\
\hline GZ 9461 & 6.16 & 3.51 & 4.84 & 13.86 & 8.80 & 11.33 & 0.444 & 0.399 & 0.422 \\
\hline PLGF 101 & 2.93 & 1.32 & 2.13 & 7.06 & 4.63 & 5.85 & 0.415 & 0.285 & 0.350 \\
\hline Egy. Hybrid 1 & 7.78 & 6.05 & 6.92 & 16.40 & 12.68 & 14.54 & 0.474 & 0.477 & 0.476 \\
\hline Mean & 5.15 & 2.96 & & 11.75 & 7.77 & & 0.435 & 0.360 & \\
\hline $\begin{array}{rr}\text { LSD } 0.05 & S \\
G \\
S G\end{array}$ & \multicolumn{3}{|c|}{$\begin{array}{l}1.22 \\
0.89 \\
1.53\end{array}$} & \multicolumn{3}{|c|}{$\begin{array}{l}2.01 \\
1.44 \\
2.49\end{array}$} & \multicolumn{3}{|c|}{$\begin{array}{l}0.06 \\
0.08 \\
0.13\end{array}$} \\
\hline
\end{tabular}

The tested rice genotypes greatly differed in their yield related characteristics (Tables 5,6 and 7). Regarding heading date, the earliest plants were obtained from the genotype Giza177, while the longest period from sowing to heading was obtained from
Giza 182 in both growing seasons (Table 5). The tallest plants were obtained by IET 1444 genotype in comparison to other genotypes. However, Egyptian Hybrid 1 genotype produced the highest numbers of tillers and panicles hill ${ }^{-1}$, longest panicle and the 
highest rate of grain filling. However, PLGF101 genotype produced the shortest plants, lowest values of number of tillers and panicles hill $^{-1}$ and filled grains panicle ${ }^{-1}$. Giza 179 had the lowest values of unfilled grains panicle $^{-1}$, while the GZ 10303 had the highest ones in both seasons. The heaviest 1000-grain was obtained from GZ 10286 and Giza 179 genotypes in the first and second seasons, respectively while the lightest 1000-grain was obtained by Egyptian jasmine in the two seasons (Table 6). This trend was previously reported by Zayed et al. (2014).

The Grain yield ha ${ }^{-1}$ of different genotypes under study varied from 2.08 to 6.73 in first season and from 2.13 to 6.92 in second one. Egyptian Hybrid 1 genotype surpassed other genotypes for producing the highest grain and biological yields in both seasons (Table 7), while the lowest ones were obtained from PLGF 101. It can be noticed that Egyptian Hybrid 1 variety excelled PLGF 101and Giza 177 genotypes in grain yield by 224.2 and $209.5 \%$, respectively. This superiority of Egyptian Hybrid 1 in grain yield may be attributed to its superiority in growth development (Table 3), leaf potassium content (Table 4) and yield attributed i.e. total numbers of tillers and panicles (Table 5) and number of filling grains per panicles (Table 6). The inbred genotype GZ 9399 had the highest grain yield comparing to the other inbred genotypes irrespective hybrid rice without significant differences with Giza 179 in first season. Harvest index was increased by planting GZ 9399, Giza 179 and Egyptian Hybrid 1 genotypes and reduced by Giza 177 and Giza 182 in first and second seasons, respectively compared to the other genotypes. Several researchers mentioned the differences in yield between rice genotypes as reported by Mansuri et al. (2012) and Hassan et al. (2013).

The interaction between salinity levels and tested rice genotypes was found to be significant for all yield and its attributes and components (Tables 5, 6 and 7). The shortest period from sowing to heading was obtained from planting the genotype Giza177 under the medium salinity, while the longest period was achieved from Giza 182 when grown under the high salinity in both seasons. The tallest plants were obtained from planting IET 1444 genotype under medium salinity, while the shortest one was achieved by growing PLGF101 genotype under high salinity. Egyptian Hybrid 1 genotype scored the highest values of tillers and panicles hill ${ }^{-1}$, while the lowest ones were obtained from PLGF 101 genotype as compared with the other genotypes under the two salinity levels. As an average of the two seasons, Egyptian Hybrid 1 genotype recorded the lowest reduction in number of panicles hill ${ }^{-1}$ (15.27\%), while PLGF 101 followed by Giza 177 recorded the highest reduction (36.02 and $34.59 \%$ ) by increasing salinity to high level. The longest panicle and the highest number of filled grain panical ${ }^{-1}$ were achieved by planting Egyptian Hybrid 1 genotype under medium salinity level, while PLGF 101 genotype when grown on high salinity level produced the shortest panicle, lowest number of filled grain panicale ${ }^{-1}$ and maximum number of unfilled grain panicale $^{-1}$. However, the lowest reduction in unfilled grains was obtained from Giza 179 followed by IET 1444 genotype in the first season and GZ 9399 genotype in the second seasons under medium salinity. The highest reduction in panicles length due to increasing salinity level from medium to high level was obtained from Egyptian Jasmine genotype which amount to $15.43 \%$ as an average of both seasons. But, the lowest reduction was recorded by GZ 9461 which was $1.37 \%$. On the other hand, the highest reduction in the filled grains as a result of increasing salinity levels were obtained from PLGF 101 which was amounted to $46.71 \%$ as an average of both seasons,. However, the lowest reduction in filled grains was achieved from Egyptian Hybrid 1 which was estimated to $13.46 \%$ in both growing 
seasons. These findings were in conformity with that reported by Zeng et al. (2002) and Zayed et al. (2014).

Giza 177 rice cultivar grown under medium soil salinity level $\left(6 \mathrm{dS} \mathrm{m}^{-1}\right)$ gave the heaviest 1000- grain weight, while Egyptian Jasmine followed by Giza 182 grown under high salinity level gave the lightest 1000 grain weight in both seasons. The highest reduction (19.80\%) in 1000- grain weight due to increasing salinity levels was recorded by Giza 177, while the lowest reduction $(4.30 \%)$ was obtained by $G Z$ 10303 genotype followed by GZ 10286 (4.64\%). The interaction effect between rice genotypes and salinity levels came to support the superiority of Egyptian hybrid 1 under salt stress including medium and high salinity levels in both seasons (Table 7), while planting PLGF 101, Giza 177, Giza 182 and GZ 10303 on high salinity level produced the lowest grain yield in both seasons. Generally, increasing salinity level significantly decreased the grain yield for all tested rice genotypes which was produced its maximum reduction (65.94 and 66.83\%) by planting Giza 177 and Giza 182 genotypes in the first and second seasons, respectively. However, the lowest reductions (23.59 and $18.85 \%$ ) were obtained by growing Egyptian Hybrid 1 and GZ 9399 in the first and second season, respectively. The highest mean values of biological yield exhibited by Egyptian Hybrid 1 grown on soil with medium salinity level, while PLGF 101 grown on soil with high salinity level produced lowest one. The highest reduction in biological yield due to increasing salinity level were recorded by Giza 182, which was estimated to $(49.32 \%)$ as an average of both seasons, the lowest reduction in biological yield by GZ9399 which was amounted to $(16.33 \%)$ in both seasons. The highest values of harvest index were obtained by GZ 9399 and Giza 179 under medium salinity level. However, Giza 177 and GZ 10303 that grown under high salinity level gave the lowest values in the first and second seasons, respectively.
High salinity stress sharply decreased yield and its attributes and components of the tested rice genotypes than those obtained by the medium salinity level. Egyptian Hybrid 1 continued to perform best under both stress conditions and generally produced the best results than other tested genotypes. Among the new promising rice genotypes, GZ 9399 was the most promise one genotype which showed better performance under two tested salinity levels over Giza 177, Giza 179 and Giza 182 cultivars irrespective Egyptian Hybrid 1 as hybrid variety. Similar results have been reported by Wanichananan et al. (2003), ElMouhamady et al. (2010) and Zayed et al. (2014). Also, Mansuri et al. (2012) showed that rice genotypes were more sensitive at the reproductive stage than the vegetative stage, where yield and yield components decreased in all the studied genotypes under salinity stress $\left(4,8\right.$ and $\left.12 \mathrm{dS} \mathrm{m}^{-1}\right)$.

\section{Genetic parameters:}

Genetic parameters studied herein for the tested rice genotypes under the two soil salinity levels, i.e. genotypic variance $\left(\sigma^{2} g\right)$, environmental variance $\left(\sigma^{2} e\right)$, phenotypic variance $\left(\sigma^{2} \mathrm{ph}\right)$, genotypic coefficient of variability (GCV), phenotypic coefficient of variability $(\mathrm{PCV})$ and heritability in broad sense $\left(H^{2} \%\right)$ were estimated as a combined analysis of variance of the two seasons for growth character (Table 8), leaf chemical constituents (Table 9) and yield and related traits (Tables 10, 11 and 12). The rice genotypes showed a wide range of genetic variation for all studied traits under the two salinity levels. The mean squares for all traits were found to be significant for growth character, leaf chemical constituents and yield and related traits. Thus, the selection procedure for all characters studied are preferred among these genotypes would be effective in all cases. Similar results were obtained by Hammoud (2004) and Akhter et al. (2014). The phenotypic coefficient of variability (PCV) was slightly higher than those of genotypic coefficient of variability 
Zayed et al.,

(GCV) for all studied traits of the twelve rice genotypes grown under the salinity levels. The value of $\mathrm{PCV} \%$ ranged from 23.68 to 52.99 but in GCV \% was varied from 21.44 to 41.93 for grain yield. In most studied traits increasing salinity level raised the contribution of environmental variability in phenotypic variability. The genetic variance played the important role than the environmental one. It can be concluded that, the relatively high genetic coefficient of variability for grain yield $\mathrm{ha}^{-1}$ indicated that the trait might be more genetic typically predominant and it would be possible to achieve further improvement.

Table (8). Estimates of genetic parameters for growth characters of rice under the two salinity levels based on the combined data.

\begin{tabular}{||l|c|c|c|c|c|c||}
\hline \multicolumn{1}{|c|}{ Characters } & \multicolumn{2}{c|}{ LAI } & \multicolumn{2}{c|}{$\begin{array}{c}\text { Dry matter } \\
\left(\mathrm{g} / \mathrm{m}^{2}\right)\end{array}$} & \multicolumn{2}{c|}{$\begin{array}{c}\text { Total chlorophyll } \\
\text { (SPAD value })\end{array}$} \\
\hline $\begin{array}{l}\text { Statistic and genetic } \\
\text { parameters }\end{array}$ & $\mathrm{S} 1$ & $\mathrm{~S} 2$ & $\mathrm{~S} 1$ & $\mathrm{~S} 2$ & $\mathrm{~S} 1$ & $\mathrm{~S} 2$ \\
\hline Mean $(\overline{\mathrm{x}})$ & 4.63 & 3.39 & 948.65 & 769.80 & 40.27 & 36.38 \\
\hline MS Genotypes & 3.63 & 5.83 & 288939.70 & 364277.50 & 16.38 & 30.06 \\
\hline MS Error & 0.257 & 0.291 & 3531.59 & 5906.51 & 1.260 & 2.113 \\
\hline Genotypic variance $\left(\sigma^{2} \mathrm{~g}\right)$ & 0.562 & 0.923 & 47568.018 & 59728.498 & 2.520 & 4.658 \\
\hline Environmental variance $\left(\sigma^{2} \mathrm{e}\right)$ & 0.257 & 0.291 & 3531.590 & 5906.510 & 1.260 & 2.113 \\
\hline Phenotypic variance $\left(\sigma^{2} \mathrm{ph}\right)$ & 0.819 & 1.214 & 51099.608 & 65635.008 & 3.780 & 6.771 \\
\hline $\begin{array}{l}\text { Genotypic coefficient } \\
\text { variance }(\mathrm{GCV})\end{array}$ & 16.194 & 28.343 & 22.991 & 31.748 & 3.942 & 5.932 \\
\hline $\begin{array}{l}\text { Phenotypic coefficient } \\
\text { variance }(\mathrm{PCV})\end{array}$ & 19.548 & 32.504 & 23.829 & 33.281 & 4.828 & 7.153 \\
\hline Heritability $\left(\mathrm{H}^{2} \%\right)$ & 68.63 & 76.03 & 93.09 & 91.00 & 66.67 & 68.79 \\
\hline
\end{tabular}

Table (9). Estimates of genetic parameters for some leaf chemical constituents of rice under the two salinity levels based on the combined data.

\begin{tabular}{|c|c|c|c|c|c|c|c|c|}
\hline \multirow{2}{*}{\begin{tabular}{l}
\multicolumn{1}{c}{ Characters } \\
Statistic and genetic \\
parameters
\end{tabular}} & \multicolumn{2}{|c|}{$\begin{array}{l}\text { Proline } \\
(\mu \mathrm{g} / \mathrm{g} \text { fWt })\end{array}$} & \multicolumn{2}{|c|}{$\mathrm{Na}^{+} \%$} & \multicolumn{2}{|c|}{$\mathrm{K}^{+} \%$} & \multicolumn{2}{|c|}{$\begin{array}{l}\mathrm{Na}^{+} / \mathrm{K}^{+} \\
\text {ratio }\end{array}$} \\
\hline & S1 & S2 & S1 & S2 & S1 & S2 & S1 & S2 \\
\hline Mean $(\bar{x})$ & 10.37 & 11.70 & 1.75 & 2.32 & 1.67 & 1.30 & 1.05 & 1.78 \\
\hline MS Genotypes & 64.17 & 113.0 & 0.282 & 0.791 & 0.293 & 0.195 & 0.451 & 1.16 \\
\hline MS Error & 1.520 & 2.942 & 0.018 & 0.013 & 0.011 & 0.010 & 0.021 & 0.028 \\
\hline Genotypic variance $\left(\sigma^{2} g\right)$ & 10.442 & 18.343 & 0.044 & 0.130 & 0.047 & 0.031 & 0.072 & 0.189 \\
\hline $\begin{array}{l}\text { Environmental variance } \\
\left(\sigma^{2} e\right)\end{array}$ & 1.520 & 2.942 & 0.018 & 0.013 & 0.011 & 0.010 & 0.021 & 0.028 \\
\hline $\begin{array}{l}\text { Phenotypic variance } \\
\left(\sigma^{2} \mathrm{ph}\right)\end{array}$ & 11.962 & 21.285 & 0.062 & 0.143 & 0.058 & 0.041 & 0.093 & 0.217 \\
\hline $\begin{array}{l}\text { Genotypic coefficient } \\
\text { variance (GCV) }\end{array}$ & 31.161 & 36.606 & 11.986 & 15.521 & 12.982 & 13.507 & 25.496 & 24.402 \\
\hline $\begin{array}{l}\text { Phenotypic coefficient } \\
\text { variance (PCV) }\end{array}$ & 33.352 & 39.432 & 14.228 & 16.281 & 14.421 & 15.544 & 28.992 & 26.150 \\
\hline Heritability $\left(\mathrm{H}^{2} \%\right)$ & 87.29 & 86.18 & 70.97 & 90.89 & 81.03 & 75.51 & 77.34 & 87.08 \\
\hline
\end{tabular}


Zayed et al.,

Table (10). Estimates of genetics parameters for some yield attributes of rice under the two salinity levels based on the combined data.

\begin{tabular}{|c|c|c|c|c|c|c|c|c|}
\hline \multirow{2}{*}{\begin{tabular}{|l|}
\multicolumn{1}{|c|}{ Characters } \\
$\begin{array}{l}\text { Statistic and genetic } \\
\text { parameters }\end{array}$ \\
\end{tabular}} & \multicolumn{2}{|c|}{$\begin{array}{l}\text { Heading date } \\
\text { (day) }\end{array}$} & \multicolumn{2}{|c|}{$\begin{array}{l}\text { Plant height } \\
\qquad(\mathrm{cm})\end{array}$} & \multicolumn{2}{|c|}{$\begin{array}{l}\text { Tillers number } \\
\text { hill }^{-1}\end{array}$} & \multicolumn{2}{|c|}{$\begin{array}{l}\text { Panicles } \\
\text { number hill }\end{array}$} \\
\hline & S1 & S2 & S1 & S2 & S1 & S2 & S1 & S2 \\
\hline Mean $(\bar{x})$ & 101.29 & 106.73 & 86.14 & 78.38 & 17.45 & 14.05 & 14.98 & 10.97 \\
\hline MS Genotypes & 178.6 & 186.42 & 425.53 & 570.61 & 34.24 & 40.12 & 27.95 & 37.97 \\
\hline MS Error & 3.841 & 2.560 & 15.43 & 12.56 & 1.423 & 1.488 & 1.056 & 0.825 \\
\hline Genotypic variance $\left(\sigma^{2} g\right)$ & 29.127 & 30.643 & 68.350 & 93.008 & 5.470 & 6.439 & 4.482 & 6.191 \\
\hline $\begin{array}{l}\text { Environmental variance } \\
\left(\sigma^{2} e\right)\end{array}$ & 3.841 & 2.560 & 15.430 & 12.560 & 1.423 & 1.488 & 1.056 & 0.825 \\
\hline $\begin{array}{l}\text { Phenotypic variance } \\
\left(\sigma^{2} \mathrm{ph}\right)\end{array}$ & 32.968 & 33.203 & 83.780 & 105.568 & 6.893 & 7.927 & 5.538 & 7.016 \\
\hline $\begin{array}{l}\text { Genotypic coefficient } \\
\text { variance (GCV) }\end{array}$ & 5.328 & 5.187 & 9.598 & 12.304 & 13.402 & 18.060 & 14.133 & 22.681 \\
\hline $\begin{array}{l}\text { Phenotypic coefficient } \\
\text { variance (PCV) }\end{array}$ & 5.669 & 5.399 & 10.626 & 13.109 & 15.045 & 20.039 & 15.710 & 24.145 \\
\hline Heritability ( $\left.\mathrm{H}^{2} \%\right)$ & 88.35 & 92.29 & 81.58 & 88.10 & 79.35 & 81.23 & 80.93 & 88.24 \\
\hline
\end{tabular}

S1: medium salinity $\left(6 \mathrm{dS} \mathrm{m}^{-1}\right) \quad \mathrm{S} 2$ : high salinity $\left(11 \mathrm{dS} \mathrm{m}^{-1}\right)$

Table (11). Estimates of genetics parameters for some yield components of rice under the two salinity levels based on the combined data.

\begin{tabular}{|c|c|c|c|c|c|c|c|c|}
\hline \multirow{2}{*}{\begin{tabular}{|l|}
\multicolumn{1}{|c|}{ Characters } \\
$\begin{array}{l}\text { Statistic and genetic } \\
\text { parameters }\end{array}$ \\
\end{tabular}} & \multicolumn{2}{|c|}{$\begin{array}{l}\text { Panicle length } \\
\text { (cm) }\end{array}$} & \multicolumn{2}{|c|}{$\begin{array}{l}\text { No. of filled grains } \\
\text { panicle }\end{array}$} & \multicolumn{2}{|c|}{$\begin{array}{l}\text { No. of unfilled } \\
\text { grains panicle }\end{array}$} & \multicolumn{2}{|c|}{$\begin{array}{l}\text { 1000-grain } \\
\text { weight }(\mathrm{g} .)\end{array}$} \\
\hline & S1 & S2 & S1 & S2 & S1 & S2 & S1 & S2 \\
\hline Mean $(\bar{X})$ & 18.89 & 16.78 & 113.74 & 79.09 & 21.09 & 37.31 & 23.45 & 21.39 \\
\hline MS Genotypes & 8.96 & 7.75 & 397.91 & 1181.9 & 215.95 & 705.26 & 8.49 & 11.05 \\
\hline MS Error & 0.211 & 0.382 & 30.69 & 76.37 & 7.127 & 13.283 & 0.671 & 0.382 \\
\hline Genotypic variance $\left(\sigma^{2} g\right)$ & 1.458 & 1.228 & 61.203 & 184.255 & 34.804 & 115.330 & 1.303 & 1.778 \\
\hline $\begin{array}{l}\text { Environmental variance } \\
\left(\sigma^{2} e\right)\end{array}$ & 0.211 & 0.382 & 30.690 & 76.370 & 7.127 & 13.283 & 0.671 & 0.382 \\
\hline Phenotypic variance $\left(\sigma^{2} p h\right)$ & 1.669 & 1.610 & 91.893 & 260.625 & 41.931 & 128.613 & 1.974 & 2.160 \\
\hline $\begin{array}{l}\text { Genotypic coefficient } \\
\text { variance }(\mathrm{GCV})\end{array}$ & 6.393 & 6.604 & 6.878 & 17.163 & 27.973 & 28.784 & 4.868 & 6.234 \\
\hline $\begin{array}{l}\text { Phenotypic coefficient } \\
\text { variance (PCV) }\end{array}$ & 6.839 & 7.562 & 8.428 & 20.412 & 30.704 & 30.396 & 5.992 & 6.871 \\
\hline Heritability ( $\left.\mathrm{H}^{2} \%\right)$ & 87.36 & 76.27 & 66.60 & 70.69 & 83.00 & 89.67 & 66.01 & 82.31 \\
\hline
\end{tabular}

S1: medium salinity $\left(6 \mathrm{dS} \mathrm{m}^{-1}\right) \quad$ S2: high salinity $\left(11 \mathrm{dS} \mathrm{m}^{-1}\right)$ 
Zayed et al.,

Table (12). Estimates of genetics parameters for grain and biological yields and harvest index of rice under the two salinity levels based on the combined data.

\begin{tabular}{|c|c|c|c|c|c|c|}
\hline Characters & $\begin{array}{r}\text { Grai } \\
\text { (tor }\end{array}$ & $\begin{array}{l}\text { yield } \\
\left(a^{-1}\right)\end{array}$ & $\begin{array}{r}\text { Biolog } \\
\text { (tor }\end{array}$ & $\begin{array}{l}1 \text { yield } \\
\left.a^{-1}\right)\end{array}$ & Harve & st index \\
\hline $\begin{array}{l}\text { Statistic and genetic } \\
\text { parameters }\end{array}$ & S1 & S2 & S1 & S2 & S1 & $\mathrm{S} 2$ \\
\hline Mean $(\bar{x})$ & 5.16 & 2.91 & 11.87 & 7.86 & 0.431 & 0.351 \\
\hline MS Genotypes & 7.61 & 9.82 & 28.43 & 29.79 & 24.22 & 103.0 \\
\hline MS Error & 0.269 & 0.889 & 1.125 & 0.692 & 1.343 & 3.891 \\
\hline Genotypic variance $\left(\sigma^{2} g\right)$ & 1.224 & 1.489 & 4.551 & 4.850 & 3.813 & 16.518 \\
\hline $\begin{array}{l}\text { Environmental variance } \\
\left(\sigma^{2} e\right)\end{array}$ & 0.269 & 0.889 & 1.125 & 0.692 & 1.343 & 3.891 \\
\hline Phenotypic variance $\left(\sigma^{2} p h\right)$ & 1.493 & 2.378 & 5.676 & 5.542 & 5.156 & 20.409 \\
\hline $\begin{array}{l}\text { Genotypic coefficient } \\
\text { variance (GCV) }\end{array}$ & 21.436 & 41.926 & 17.972 & 28.018 & 453.051 & 1157.907 \\
\hline $\begin{array}{l}\text { Phenotypic coefficient } \\
\text { variance (PCV) }\end{array}$ & 23.676 & 52.987 & 20.071 & 29.950 & 526.832 & 1287.080 \\
\hline Heritability $\left(\mathrm{H}^{2} \%\right)$ & 81.97 & 62.61 & 80.18 & 87.51 & 73.95 & 80.94 \\
\hline
\end{tabular}

S1: medium salinity $\left(6 \mathrm{dS} \mathrm{m}^{-1}\right)$

S2: high salinity $\left(11 \mathrm{dS} \mathrm{m}^{-1}\right)$

The phenotypic coefficient of variability was higher than genotypic one in all studied traits, but the most portion of PCV was more contributed by genotypic component than by environmental one. This phenomenon is in agreement with that mentioned by Shehata et al. (2009), El-Mouhamady et al. (2010) and Akhter et al. (2014).

Heritability in broad sense was computed and the obtained results were illustrated in Tables (8, 9, 10, 11 and 12). High heritability estimates in broad sense were detected for all studied traits under different salinity conditions. All heritability values of morphological, chemical and yield traits were highly providing that genetic variance plays the important role than environmental variance (Shehata et al., 2004). The differences in magnitudes of broad sense heritability estimates were found in most traits under investigation would indicate and ascertained the presence of both additive and non-additive genetic variance in controlling traits under this different salinity conditions. The same conclusions were previously reached by Kashif and Khaliq
(2004), Shehata et al. (2009) and Lingaiah (2015).

\section{Conclusion}

Rice is moderately sensitive to salinity, but genotypes vary in their tolerance. The increase of salinity level was decreased plant growth and yield components. Therefore, developing salinity tolerance rice genotypes is a very important approach not only for increasing yields, but also for conquering saline soils. To develop and sustain high yielding rice genotypes combined with salinity tolerance, it is needed to know adequate genetic information about the type and magnitude of the genetic and environmental variations within the genotypes. Increasing salinity stress pronounced restricted the morphological and physiological traits. Planting salt tolerant genotypes significantly and markedly decreased the growth and yield reductions. It could be concluded that great diversity was observed among rice genotypes for different salinity levels during growth and maturity stages. Egyptian Hybrid 1 genotype 
scored the highest mean values of most yield components comparing with other genotypes under different salinity levels.

\section{REFERENCES}

Akhter, M.S., M. Rizwan, M. Akhter, M. Naeem, W. Hussain, F. Elahi and M. Latif (2014). Genotypic and Phenotypic Condition Coefficient Analysis for Yield and Yield Related Components in Basmati Rice (Oryza sativa L.). American-Eurasian J. Agric. \& Environ. Sci., 14 (12): 1402-1404.

Ali, M.N., L. Yeasmin, S. Gantait, R. Goswami and S. Chakraborty (2014). Screening of rice landraces for salinity tolerance at seedling stage through morphological and molecular markers. Physiology and Molecular Biology Plants, 20(4): 411- 423. doi: $10.1007 /$ s12298014-0250-6

Allard, R.W. (1999). Principles of Plant Breeding, $2^{\text {nd }}$ ED. John Wiley and Sons. Inc. New York, USA, pp. 485.

Al-Salim, S.H.F., R. Al-Edelbi, F. Aljbory and M.M. Saleh (2016). Evaluation of the performance of some rice (oryza sativa l.) varieties in two different environments. Open Access Library Journal, 3: 1-7. http://dx.doi.org/10.4236/oalib.1102294

Aref, F. and H.E. Rad (2012). Physiological characterization of rice under salinity stress during vegetative and reproductive stages. Indian Journal of Science and Technology, 5 (4): 2578-2586.

Bates, L.S., R.P. Waldren and I.D. Teare (1973). Rapid determination of free proline for water stress studies. Plant and Soil, 39 (1): 205-207.

Black, C.D., D.D. Evans, L.E. Ensminger, J.L. White and F.E. Clark (1965). Methods of soil analysis. Part I and II. Amer. Soc. of Agron. in Publisher, Madison-Wisconsin, USA.

Burton, G. W. (1952). Quantitative inheritance in grass. Proc. $6^{\text {th }}$. Int. Crossed Cong. 1:227-283.

Castillo, E.G., T.P. Tuong, A.M. Ismail and K. Inubushi (2007). Response to salinity in rice: comparative effects of osmotic and ionic stresses. Plant Prod.Sci., 10 (2) :159-170.
Chapman, H.D. and P.F. Pratt (1961). Methods of analysis for soils, plants and waters. Univ. of Calif. Division of Agricultural Sciences.

De Leon, T.B., S. Linscombe, G. Gregorio and P.K. Subudhi (2015). Genetic variation in Southern USA rice genotypes for seedling salinity tolerance. Front. Plant Sci. 6:374. doi: 10.3389/fpls.2015.00374

El-Mouhamady, A.A., I.S. El-Demardash and K.A. Aboud (2010). Biochemical and molecular genetic studies on rice tolerance to salinity. Journal of American Science, 6(11): 521-535.

Falconer, D.S. and T.F.C. Mackay (1996). Introduction to Quantitative Genetics. Longman, Harlow, Essex.

FAO (2008). Global network on integrated soil management for sustainable use of salt-affected soils.

Gupta, B. and B. Huang (2014). Mechanism of salinity tolerance in plants: physiological, biochemical, and molecular characterization. Int J. Genomics, 1-18. doi: 10.1155/2014/701596.

Hamayun, M., S.A. Khan, A. Khan, Z.K. Shinwari, J. Hussain, E. Sohn, S. Kang, Y. Hakim, M. A. Khan and I. Lee (2010). Effect of salt stress on growth attributes and endogenous growth hormones of soybean cultivar Hwangkeumkong. Pak. J. Bot., 42(5): 3103-3112.

Hammoud, S.A.A. (2004). Inheritance of some quantities characters in rice. Ph.D Thesis, Fac. of Agric., Minufiya Univ., Egypt.

Hammoud, S.A.A. and W. S. Gabr (2014). Behavior of some rice genotypes as affected by some major diseases infection under different condition. J. Plant prot. and path., Mansoura Univ., 5(9): 871-890.

Hassan, H.M., W.M. El-Khoby and A.A. ElHissewy (2013). Performance of some rice genotypes under both salinity and water stress conditions in Egypt. J. Plant Production, Mansoura Univ., 4 (8):1235 1255.

Johnson, H. W., H. F. Robinson and R.E. Comstock (1955). Estimates of genetic and environmental variability in soybean. Agron. J. 47:314-318. 
Kashif, M. and I. Khaliq (2004). Heritability, correlation and path coefficient analysis for some metric traits in wheat. Int. J. Agri. Biol., 6 (1): 138-142.

Lingaiah, N. (2015). Genetic variability, heritability and genetic advance in rice (Oryza sativa L.). Asian J. Environ. Sci., 10 (1): $110-112$.

Mansuri, S.M., N.B. Jelodar and N. Bagheri (2012). Evaluation of rice genotypes to salt stress in different growth stages via phenotypic and random amplified polymorphic DNA (RAPD) marker assisted selection. African Journal of Biotechnology, 11 (39): 9362-9372. doi: 10.5897/AJB11.1490

Mohamed, E.S., E.G. Morgun and S.M. Goma (2011). Assessment of soil salinity in the Eastern Nile Delta (Egypt) using Geoinformation techniques.Moscow Univ. Soil Sci. Bull., 66 (1), 11-14.

Mohammadi, N.G., R.K. Singhb, A. Arzanic, A.M. Rezaiec, H. Sabourid and G.B. Gregoriob (2010). Evaluation of salinity tolerance in rice genotypes. Int. J. Plant Prod. 4(3): 199-207.

Qadir, M., A.D. Noble, S. Schubert, R.J. Thomas and A. Arslan (2006). Sodicityinduced land degradation and its sustainable management: problems and prospects. Land Deg. Devel., 17, 661676. doi:10.1002/ldr.751

Ramezani, E., M.G. Sepanlou and H.A.N. Badi (2011). The effect of salinity on the growth, morphology and physiology of Echium amoenum Fisch. \& Mey. African Journal of Biotechnology, 10 (44): 87658773.

Sankar, P.D., M.A.A.M. Saleh and C.I. Selvaraj (2011). Rice breeding for salt tolerance. Research in Biotechnology, 2 (2): 1-10.

Shehata, S.M., A.E. Draz, A.A. Abd Allah and B.A. Zayed (2004). Genetic studies on some morphological characters as indicators of salt and drought tolerance in rice. Egypt. J. Agric. Res. 82(1):101-119.

Shehata, S.M., M.H. Ammar, A.F. Abdelkalik and B.A. Zayed (2009). Morphological, molecular and biochemical evaluation of Egyptian jasmine rice variety and its M5 derived mutants. African Journal of Biotechnology, 8 (22): 6110-6116.

Snedecor, G.W. and W.G. Cochran (1980). Statistical Methods, $7^{\text {th }}$ Ed. The lowa State Univ. Press, Ames. lowa, USA.

Tavakkoli, E., F. Fatehi, S. Coventry, P. Rengasamy and G.K. McDonald (2011). Additive effects of $\mathrm{Na}^{+}$and $\mathrm{Cl}^{-}$ions on barley growth under salinity stress. J Exp Bot., 62(6):2189-203. doi: 10.1093/jxb/erq422.

Torabi, M. (2014). Physiological and biochemical responses of plants to salt stress. The $1^{\text {st }}$ International Conference on New Ideas in Agriculture, Islamic Azad University Khorasgan Branch, 2627 Jan., Isfahan, Iran.

Wanichananan, P., C. Kirdmanee and C. Vutiyano (2003). Effect of salinity on biochemical and physiological characteristics in correlation to selection of salt tolerance in aromatic rice (Oryza sativa L.), Science Asia, 29: 333-339.

Wolf, B. (1982). A comprehensive system of leaf analysis and its use for diagnosing crop nutrient status, Communications in Soil Science and Plant Analysis, 13:1035-1059.

Yoshida, S., D.A. Forno, J.H. Cock and K.A. Gomez (1976). Laboratory Manual for Physiology Studies of Rice. $3^{\text {th }} \mathrm{Ed}$, The International Rice Research Institute, Los Baños, Laguna, Philippines, 1-82.

Zayed, B.A., A.A. Abou Kalifa and H.F. ElMowafi (2005). Seedling vigor of hybrid rice as related to seed rate in nursery under saline soil. Egypt. J. of Agric. Res., 83(5B): 423-435.

Zayed, B.A., A.K. Salem and O.A.M. Ali (2014). Physiological characterization of Egyptian salt tolerant rice varieties under different salinity levels. Life Science Journal, 11(10): 1264-1272.

Zeng, L., J.A. Poss, C. Wilson, A.E. Draz, G.B. Gregorio and C.M. Grieve (2003). Evaluation of salt tolerance in rice genotypes by physiological characters. Euphytica, 129:281-292.

Zeng, L., M.C. Shannon and C.M. Grieve (2002). Evaluation of salt tolerance in rice genotypes by multiple agronomic parameters. Euphytica 127: 235-245. 


\title{
الأداء الفسيولوجى والوراثى لبعض التراكيب الوراثية للأرز النامية بأراضى متوسطة وعالية الملوحة
}

\author{
بسيونى عبد الرازق زايل(1) ، أسامه على محمد على (2)، سعيا على حمود(1)

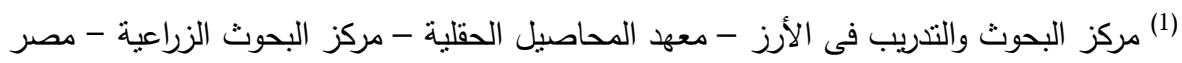

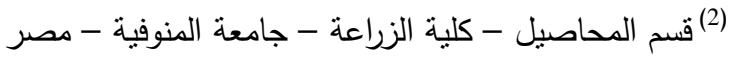

تُعد الملوحة أحد الاجهادات البيئية الى تؤثر سلباً على انتاج الارز فى العالم. لذا أجريت تجربتان حقليتان بالمزرعة التجريبية لمحطة البحوث الزراعية بالسرو - محافظة دمياط - مصر بهدف دراسة تأثثر مستويات ملوحة

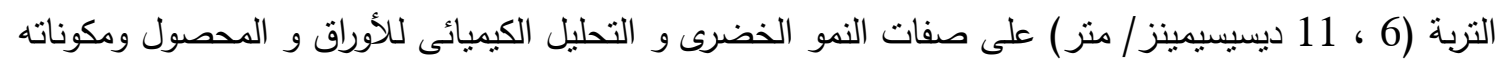

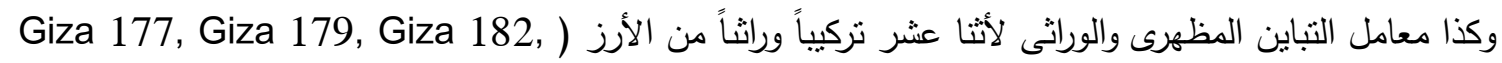
Egyptian Jasmine, GZ 10303, GZ 10305, IET 1444, GZ 10286, GZ 9399, GZ 9461, (PLGF101, Egyptian Hybrid 1

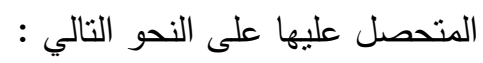

1- أدى ارتفاع ملوحة التربة من المستوى المتوسط (6 ديسيسيمينز / متر ) إلى المستوى العالى (11 ديسيسيمينز /

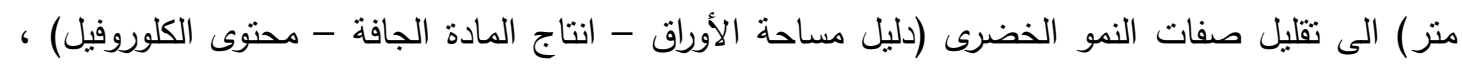
والصفات المحصولية (تاريخ طرد الداليات - ارتفاع النبات - عدد الأشطاء بالجورة - عدد الداليات بالجورة -

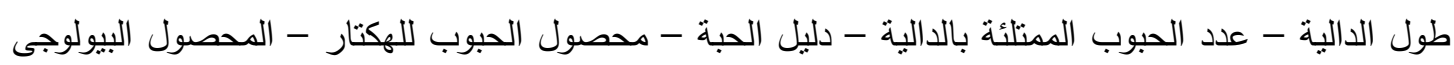

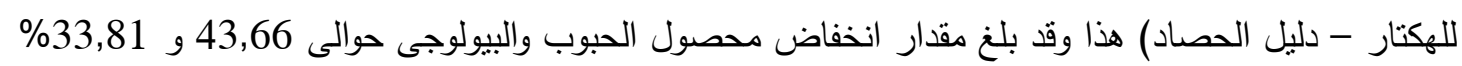

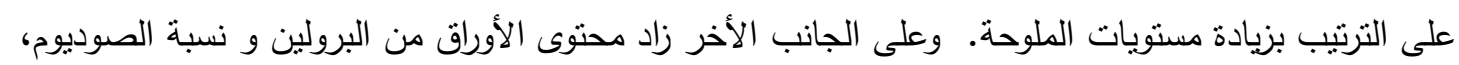

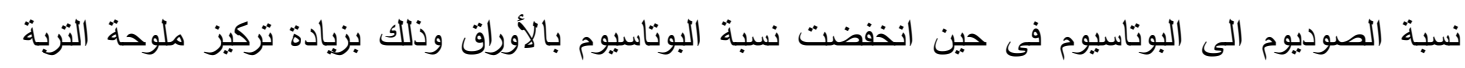

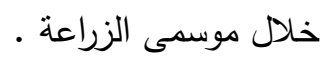

2- تنثير النتائج إلى وجود اختلافات معنوية بين التراكيب الوراثية المختبرة فى صفات النمو والمحصول المدروسة. حيث تفوق الصنف هجين مصرى 1 (Egyptian Hybrid 1) على التراكيب الوراثية الأخرى المختبرة فى كل من صفات النمو الخضرى ، عدد الأشطاء والداليات بالجورة ، طول الدالية ، عدد الحبوب الممتلئة بالدالية ،

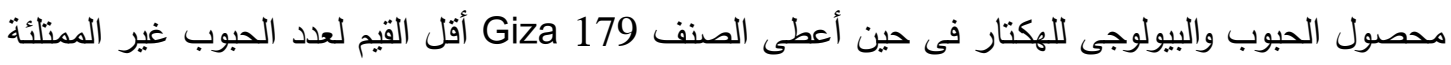

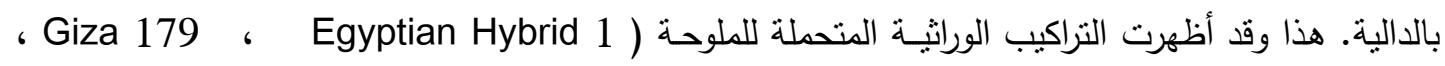

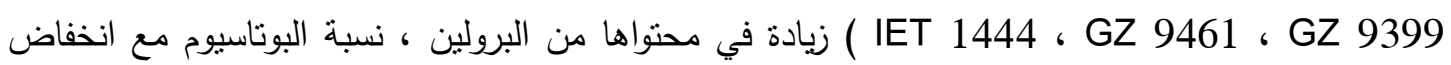

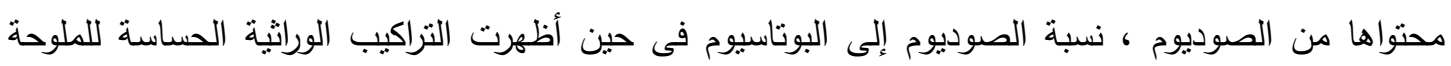
اتجاهاً معاكساً لذلك. من ألكأ. 


\section{Zayed et al.,}

3- أوضحت نتائج التفاعل وجود اختلافات معنوية بين مستويات الملوحة المختبرة والتراكيب الوراثية للأرز لجميع الصفات المدروسة. هذا وقد تفوق الصنف هجين مصرى 1 (Egyptian Hybrid 1) فى معظم الصفات

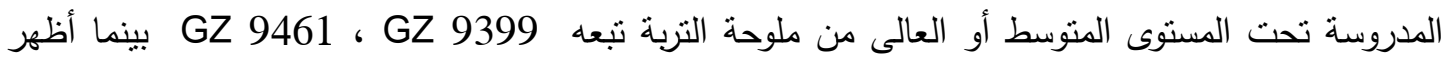
التركيب الوراثى 101 أداءاً منخفضاً في تحمل مستويات الملوحة الدختبرة لمعظم الصفات المدروسة

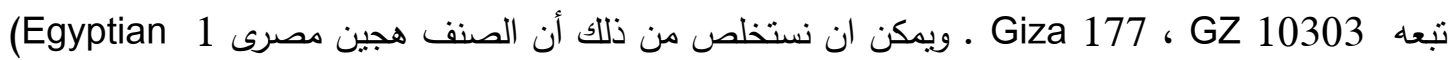
Hybrid 1)

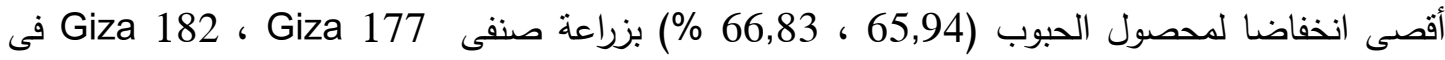
الموسم الاول والثانى على الترتيب فى حين تحقق أقل انخفاضا فى محصول الحبوب (23,59 ، 18,85\%) بزراعة كل من Egyptian Hybrid 1 ، GZ 9399 خلال الموسم الاول والثانى على الترتيب . 4- ثُنير النتائج إلى أن تقديرات معامل التباين المظهرى (PCV) كانت أعلى قليلا من تقديرات معامل التباين الوراثى (GCV) لجميع الصفات المدروسة للتراكيب الوراثية النامية تحت مستويين من ملوحة التربة حيث بلغ مدئ

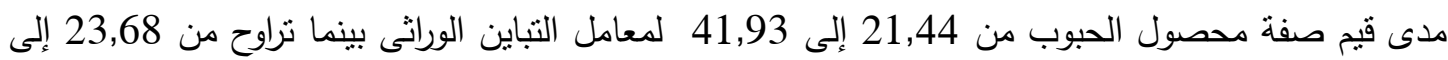
52,99 لمعامل التباين المظهرى ـ وقد أدى ارتفاع ملوحة التربة الى زيادة مساهمة التغير البيئي في التباين

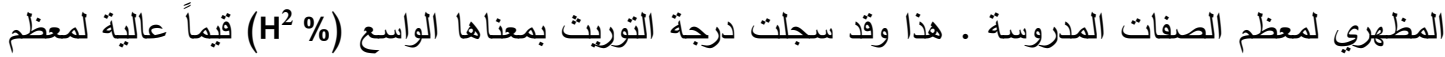

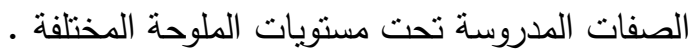


Menoufia J. Plant Prod., Vol. 1 October (2016): 155 - 175 